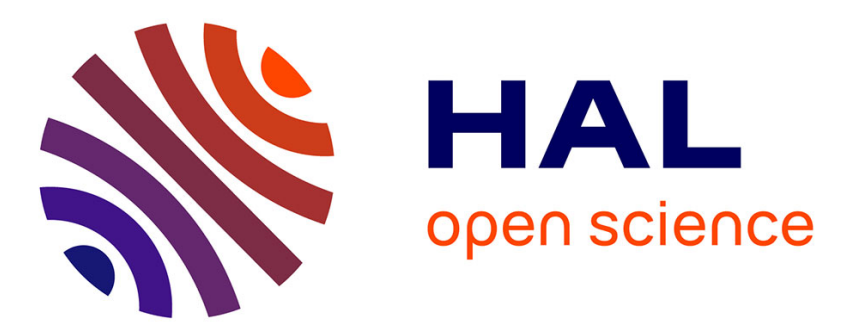

\title{
Fine tuning of reactivity and structure of bis $(\sigma)$ borate and borate complexes of manganese by systematic ligand variation
}

\author{
C. Nandi, K. Saha, S. Gomosta, V. Dorcet, S. Ghosh
}

\section{- To cite this version:}

C. Nandi, K. Saha, S. Gomosta, V. Dorcet, S. Ghosh. Fine tuning of reactivity and structure of bis $(\sigma)$ borate and borate complexes of manganese by systematic ligand variation. Polyhedron, 2019, 172, pp.191-197. 10.1016/j.poly.2019.04.041 . hal-02161850

\section{HAL Id: hal-02161850 \\ https://hal-univ-rennes1.archives-ouvertes.fr/hal-02161850}

Submitted on 1 Jul 2019

HAL is a multi-disciplinary open access archive for the deposit and dissemination of scientific research documents, whether they are published or not. The documents may come from teaching and research institutions in France or abroad, or from public or private research centers.
L'archive ouverte pluridisciplinaire HAL, est destinée au dépôt et à la diffusion de documents scientifiques de niveau recherche, publiés ou non, émanant des établissements d'enseignement et de recherche français ou étrangers, des laboratoires publics ou privés. 


\section{Fine tuning of reactivity and structure of bis( $\sigma$ )borate and borate complexes of manganese by systematic ligand variation}

Chandan Nandi ${ }^{\mathrm{a}}$, Koushik Saha ${ }^{\mathrm{a}}$, Suman Gomosta ${ }^{\mathrm{a}}$, Vincent Dorcet ${ }^{\mathrm{b}}$, Sundargopal Ghosh ${ }^{\mathrm{a}, *}$

Abstract: The complexes with $f a c-\left[\mathrm{M}(\mathrm{CO})_{3}\right]^{+}$units of group-7 metals are interesting synthons for the development of target-specific drugs. Therefore, thermolysis reaction of $\operatorname{Re}_{2}(\mathrm{CO})_{10}$ with yarious borate ligands have been investigated as a possible route to isolate bis $(\sigma)$ borate complexes of rhenium. The reaction of trihydrobis(benzothiazol-2-yl)amideborate, $\mathrm{Na}\left[\left(\mathrm{H}_{3} \mathrm{~B}\right)\right.$ bbza] (bbza = bis(benzothiazol2-yl)amine) with $\operatorname{Re}_{2}(\mathrm{CO})_{10}$ led to the formation of distorted octahedral rhenium complexes $\left[(\mathrm{CO})_{2} \operatorname{Re}\left\{\mathrm{N}\left(\mathrm{C}_{7} \mathrm{H}_{4} \mathrm{NS}\right)_{2}\right\}_{2}\right], 1$ and $\left[(\mathrm{CO})_{2} \mathrm{Re}\left\{\mathrm{N}\left(\mathrm{C}_{7} \mathrm{H}_{4} \mathrm{NS}\right)_{2}\right\}\left\{\mathrm{C}_{6} \mathrm{H}_{4} \mathrm{~N}(\mathrm{Me}) \mathrm{O}\right\}\right], 2$. In order to increase the library of complexes conatining $f a c-\left\{\mathrm{M}(\mathrm{CO})_{3}\right\}^{+}$moieties as well as to check the lability of the metal-carbonyl bond, reactivity of manganese borate complexes [Mn(CO) $\left.)_{3}(\mu-\mathrm{H})_{2} \mathrm{BHNCSC}_{6} \mathrm{H}_{4}(\mathrm{NR})\right]$, $3\left(\mathrm{R}=\mathrm{NCSC}_{6} \mathrm{H}_{4}\right)$ and $\left[\mathrm{Mn}(\mathrm{CO})_{3}\left\{\mathrm{\kappa}^{3}-\mathrm{S}, \mathrm{S}^{\prime}, \mathrm{H}-\mathrm{H}_{2} \mathrm{~B}(\mathrm{mbz})_{2}\right\}\right], 6$ (mbz = 2-mercapto-benzothiazolyl) with different ligands were carried out. Photolysis of 3 with excess phosphine ligands $\left(\mathrm{PPh}_{2} \mathrm{Me}\right.$ or $\left.\mathrm{PMe}_{2} \mathrm{Ph}\right)$ yielded manganese phosphine complexes $\left[\mathrm{Mn}(\mathrm{CO})_{2}\left(\mathrm{PL}_{2} \mathrm{~L}^{\prime}\right)_{2}\left\{\mathrm{~N}\left(\mathrm{C}_{7} \mathrm{H}_{4} \mathrm{NS}\right)_{2}\right\}\right],\left[\mathbf{4 a}: \mathrm{L}=\mathrm{Ph}, \mathrm{L}^{\prime}=\mathrm{Me}\right.$; 4b: $\left.\mathrm{L}=\mathrm{Me}, \mathrm{L}^{\prime}=\mathrm{Ph}\right]$. Interestingly, the reaction of 3 with ${ }^{t} \mathrm{BuNC}$ yielded mono/bis $\left({ }^{(} \mathrm{BuNC}\right)-$ substituted manganese borate complexes $\left[\mathrm{Mn}(\mu-\mathrm{H})_{2}\left(\mathrm{BHNCSC}_{6} \mathrm{H}_{4}\right)(\mathrm{NR})(\mathrm{CO})_{\mathrm{x}} \mathrm{L}_{\mathrm{y}}\right], \mathbf{5 a}-\mathbf{b}(\mathbf{5 a}: \mathrm{x}=2, \mathrm{y}$ $\left.=1 ; \mathbf{5 b}: \mathrm{x}=1 ; \mathrm{y}=2 ; \mathrm{L}={ }^{t} \mathrm{BuNC} ; \mathrm{R}=\mathrm{NCSC}_{6} \mathrm{H}_{4}\right)$ and $\left[\mathrm{Mn}(\mu-\mathrm{H})_{2} \mathrm{BH}\left\{\mathrm{N}\left(\mathrm{NCSC}_{6} \mathrm{H}_{4}\right)_{2}\right\}(\mathrm{CO})\left({ }^{t} \mathrm{BuNC}\right)_{2}\right]$, $\mathbf{5 c}$. Compounds $\mathbf{5 b}$ and $\mathbf{5 c}$ are structural isomers with a different coordination mode of the bbza ligand. Under similar reaction conditions, photolysis of 6 with $\mathrm{PPh}_{3}$ in toluene generated borate complex of manganese $\left[\mathrm{Mn}\left(\mathrm{CO}_{2}\right)\left\{\mathrm{\kappa}^{3}-\mathrm{S}, \mathrm{S}^{\prime}, \mathrm{H}-\mathrm{H}_{2} \mathrm{~B}(\mathrm{mbz})_{2}\right\}\left(\mathrm{PPh}_{3}\right)\right]$, 7. All the compounds were characterised by multi-nuclear NMR, IR spectroscopy and mass spectrometry. Density functional theory (DFT) calculations were carried out to investigate the bonding and electronic structures of these compounds.

Keywords: Bis( $(\sigma)$ borate, Manganese, Rhenium, Phosphine, ${ }^{\mathrm{t}} \mathrm{BuNC}$

\footnotetext{
a Department of Chemistry, Indian Institute of Technology Madras, Chennai 600 036, India.

${ }^{\mathrm{b}}$ Univ Rennes, CNRS, ISCR (Institut des Sciences Chimiques de Rennes) - UMR 6226, F-35000 Rennes, France.

*Corresponding Author. Phone: (+91) 442257 4230; Fax: (+91) 4422574202.

E-mail address: $\underline{\text { sghosh@,iitm.ac.in }}$
} 


\section{Introduction}

In coordination chemistry, transition metal complexes containing borate ligands such as poly(pyrazolyl)borate, poly(methimazolyl)borate, poly(2-mercapto-thiazolyl)borate, earmarked a unique place due to their different chelation modes towards the transition metals [1-3]. Several examples of borate complexes of group 6-10 metals, especially with late transition metals, are known which are structurally characterized. The development of borate complexes of group-7 metals have been explored intensively in the case of rhenium and technetium as compared with manganese [4]. In 2000, Hartwig first reported the $\sigma$-borane complexes of manganese followed by Shimoi in 2001 [56]. Later Wagner, Rabinovich, Peters and others reported manganese complexes of borate ligands containing various heterocyclic rings [7-8]. As shown in Figure 1, these borate ligands exhibit different types of coordination mode towards the metal centre. Subsequently, bis $(\sigma)$ borate complexes of $\mathrm{Re}$ and ${ }^{99 \mathrm{~m}} \mathrm{Tc}$, in which the ligand binds the metal centre in $\left(\kappa^{3}-\mathrm{H}, \mathrm{H}, \mathrm{S}\right)$ coordination mode, were synthesized and structurally characterized by Santos et al. The $f a c-\left[\operatorname{Re}\left\{\kappa^{3}-\mathrm{H}(\mu-\mathrm{H})_{2} \mathrm{~B}\left(\mathrm{tim}^{\mathrm{Bupip}}\right)\right\}(\mathrm{CO})_{3}\right]$

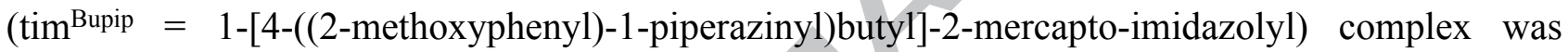
found to be potential for the design of CNS receptor ligand radiopharmaceutical [4e].

There are very few examples of manganese borate complexes known in which the scorpionate ligands bind the metal centre in $\left(\kappa^{3}-\mathrm{E}, \mathrm{H}, \mathrm{H}\right)(\mathrm{E}=$ hetero atom $)$ fashion. The foremost example of this type of complexes of manganese containing 2-(methylamido)pyridine-borane as a tripod $\left(\kappa^{3}-\mathrm{N}, \mathrm{H}, \mathrm{H}\right)$ ligand was synthesized and structurally characterized by Cabeza et al. We [9] and others [10] have recently reported several $\sigma$-borate complexes of early and late transition metals by developing a new synthetic route from $\left[\mathrm{Cp}^{*} \mathrm{MCl}_{2}\right]_{2}\left(\mathrm{M}=\mathrm{Ru}, \mathrm{Rh}\right.$ or Ir) and $\mathrm{Na}\left[\mathrm{H}_{2} \mathrm{~B}(\mathrm{mbz})_{2}\right][9,11]$. We have further demonstrated that these types of complexes of manganese containing $\left\{\mathrm{M}(\mathrm{CO})_{3}\right\}$ fragment can also be accessible using the transmetalation approach [9d,9j]. Successively, we have synthesized and structurally characterized a series of borate complexes of group 7 metals using various borate ligands those show a stronger preference for either the $\left(\kappa^{3}-\mathrm{H}, \mathrm{H}, \mathrm{N}\right)$ or $\left(\kappa^{3}-\mathrm{H}, \mathrm{S}, \mathrm{S}\right)$ coordination mode [11]. Therefore, the synthesis and reactivity of these borate complexes containing group-7 $\left\{\mathrm{M}(\mathrm{CO})_{3}\right\}$ fragment became of our particular interest. Herein, we describe the reactivity of bis $(\sigma)$ borate and borate complexes of manganese with different type of stronger $\sigma$-donor and weaker $\pi$-acceptor ligands such as, phosphines and ${ }^{t} \mathrm{BuNC}$ that generated different types of phosphine and bis $(\sigma)$ borate complexes of manganese, respectively. 


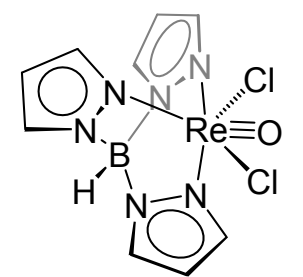

Davison, 1984

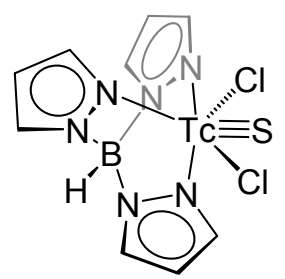

Tisato and Duatti, 1993

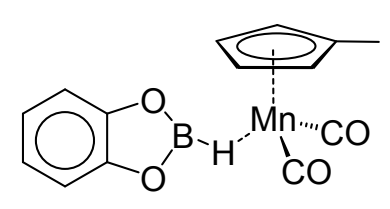

Hartwig, 2000

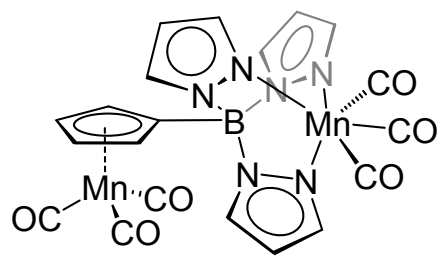

Wagner, 2003

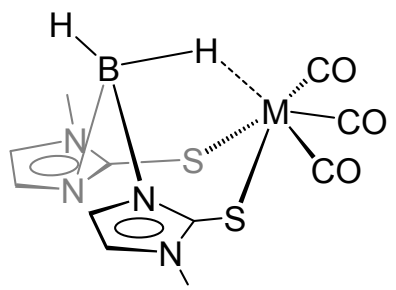

$M=M n ;$ Rabinovich, 2005

$\mathrm{M}=\mathrm{Re}$; Santos, 2009

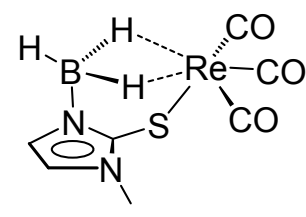

Santos, 2006

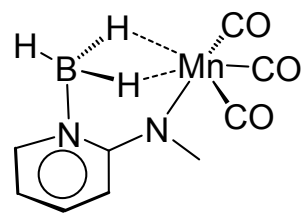

Cabeza, 2017

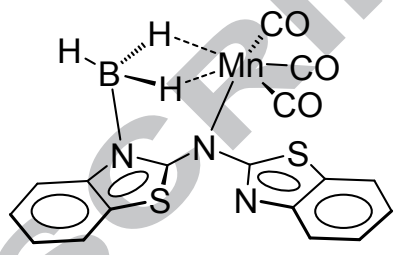

Ghosh, 2017

Figure 1. Various examples of borane/borate complexes of group 7 metals.

\section{Experimental details}

\subsection{General methods and instrumentation:}

All of the syntheses were carried out under argon atmosphere with standard Schlenk line and glove box techniques. $\mathrm{Na}\left[\left(\mathrm{H}_{3} \mathrm{~B}\right)\right.$ bbza] [11,12], $\mathrm{Na}\left[\mathrm{H}_{2} \mathrm{~B}(\mathrm{mbz})_{2}\right]$ [3e], compounds 3 [11] and 6 [9j], were prepared according to literature methods and other chemicals $\mathrm{Re}_{2}(\mathrm{CO})_{10},{ }^{t} \mathrm{BuNC}, \mathrm{PPh}_{3}, \mathrm{PPh}_{2} \mathrm{Me}$ and $\mathrm{PMe}_{2} \mathrm{Ph}$ were obtained commercially. The external reference for the ${ }^{11} \mathrm{~B}\left\{{ }^{1} \mathrm{H}\right\} \mathrm{NMR}\left[\mathrm{Bu}_{4} \mathrm{~N}\right]\left[\mathrm{B}_{3} \mathrm{H}_{8}\right]$ [13] was synthesized according to literature method. Thin-layer chromatography was carried out on $250 \mathrm{~mm}$ diameter aluminum supported silica gel TLC plates. NMR spectra were recorded on a 500 $\mathrm{MHz}$ Bruker FT-NMR spectrometer. Residual solvent protons were used as reference $\left(\delta, \mathrm{CDCl}_{3}, 7.26\right.$ ppm), while a sealed tube containing $\left[\mathrm{Bu}_{4} \mathrm{~N}\right]\left[\mathrm{B}_{3} \mathrm{H}_{8}\right]$ in benzene- $d_{6}(\delta$, ppm, -30.07) was used as an external reference for the ${ }^{11} \mathrm{~B}\left\{{ }^{1} \mathrm{H}\right\}$ NMR. Mass spectra were recorded on a BrukerMicroTOF-II mass spectrometer in ESI ionization mode. Infrared spectra were recorded on a JASCO FT/IR-4100 spectrometer. The photoreactions described in this report were conducted in a Luzchem LZC-4V photoreactor, with irradiation at 254-350 $\mathrm{nm}$.

\subsection{Synthesis of 2}

In a flame-dried Schlenk tube, a solution of $\operatorname{Re}_{2}(C O)_{10}(0.100 \mathrm{~g}, 0.15 \mathrm{mmol})$ in $10 \mathrm{~mL}$ of toluene was added to $10 \mathrm{~mL}$ of THF solution of $\mathrm{Na}\left[\left(\mathrm{H}_{3} \mathrm{~B}\right) \mathrm{bbza}\right](0.195 \mathrm{~g}, 0.60 \mathrm{mmol})$ and was heated for $18 \mathrm{~h}$ 
at $80{ }^{\circ} \mathrm{C}$. The color of the reaction mixture changed from colourless to pale green. The solvent was then evaporated in vacuum; residue was extracted into hexane $/ \mathrm{CH}_{2} \mathrm{Cl}_{2}(60: 40 \mathrm{v} / \mathrm{v})$ and passed through Celite. After removal of solvent from filtrate, the residue was subjected to chromatographic workup using silica-gel TLC plates. Elution with hexane/ $\mathrm{CH}_{2} \mathrm{Cl}_{2}(60: 40 \mathrm{v} / \mathrm{v})$ yielded green solid $1(0.014 \mathrm{~g}$, $11 \%$ ) and green solid $2(0.056 \mathrm{~g}, 5 \%)$.

2. MS $\left(\mathrm{ESI}^{+}\right): \mathrm{m} / z$ calculated for $\left[\mathrm{ReC}_{23} \mathrm{H}_{15} \mathrm{~N}_{4} \mathrm{~S}_{2} \mathrm{O}_{3}+\mathrm{H}\right]^{+}$647.0, found 647.0, $\mathrm{IR}\left(\mathrm{CH}_{2} \mathrm{Cl}_{2}\right): v$ bar $=$ $1984,1887 \mathrm{~cm}^{-1}$ (CO) [14].

\subsection{Synthesis of $4 \boldsymbol{a}$}

In a flame-dried Schlenk tube, bis $(\sigma)$ borate complex $\left[\mathrm{Mn}(\mathrm{CO})_{3}(\mu-\mathrm{H})_{2} \mathrm{BH}\left(\mathrm{RN}_{2} \mathrm{CSC}_{6} \mathrm{H}_{4}\right)\right]$, $(\mathrm{R}=$ $\left.\mathrm{NCSC}_{6} \mathrm{H}_{4}\right) 3(0.100 \mathrm{~g}, 0.23 \mathrm{mmol})$ and $\mathrm{PPh}_{2} \mathrm{Me}(0.168 \mathrm{~g}, 0.69 \mathrm{mmol})$ were dissolved in $15 \mathrm{~mL}$ of toluene and allowed irradiation at $254-350 \mathrm{~nm}$ for $1 \mathrm{~h}$ at room temperature. The colour of the reaction mixture changed from yellow to orange. Then the solvent was evaporated in vacuum; residue was extracted into hexane/ $\mathrm{CH}_{2} \mathrm{Cl}_{2}(70: 30 \mathrm{v} / \mathrm{v})$ and passed through Celite. After the removal of solvent from filtrate, the residue was subjected to chromatographic workup using silica-gel TLC plates. Elution with hexane/ $\mathrm{CH}_{2} \mathrm{Cl}_{2}(70: 30 \mathrm{v} / \mathrm{v})$ yielded yellow solid $4 \mathbf{a}(0.045 \mathrm{~g}, 22 \%)$.

4a: $\mathrm{HRMS}\left(\mathrm{ESI}^{+}\right): \mathrm{m} / z$ calculated for $\left[\mathrm{C}_{42} \mathrm{H}_{34} \mathrm{MnN}_{3} \mathrm{O}_{2} \mathrm{~S}_{2} \mathrm{P}_{2}+\mathrm{H}\right]^{+} 794.1026$, found 794.1038; ${ }^{1} \mathrm{H}$ NMR (500 MHz, $\left.\mathrm{CDCl}_{3}, 22{ }^{\circ} \mathrm{C}\right): \delta=7.60-7.01(\mathrm{~m}, 28 \mathrm{H}, \mathrm{Ph}), 1.79 \mathrm{ppm}\left(\mathrm{s}, 6 \mathrm{H}, \mathrm{CH}_{3}\right) ;{ }^{13} \mathrm{C}\left\{{ }^{1} \mathrm{H}\right\} \mathrm{NMR}(125$ $\mathrm{MHz}, \mathrm{CDCl}_{3}, 22^{\circ} \mathrm{C}$ ): $\delta=169.6(\mathrm{~s}, \mathrm{C}=\mathrm{N}), 153.1,146.5$ (s, CN), 136.0, 135.9 (s, CS), 132.1-115.7 (s, bbza), $155 \mathrm{ppm}$ (s, Me); ${ }^{31} \mathrm{P}\left\{{ }^{1} \mathrm{H}\right\} \mathrm{NMR}\left(202 \mathrm{MHz}, \mathrm{CDCl}_{3}, 2{ }^{\circ} \mathrm{C}\right): \delta=50.7 \mathrm{ppm}$; IR $\left(\mathrm{CH}_{2} \mathrm{Cl}_{2}\right)$ : vbar $=1928,1851 \mathrm{~cm}^{-1}(\mathrm{CO})$.

\subsection{Synthesis of $\mathbf{4 b}$}

In a flame-dried Schlenk tube, complex $3(0.100 \mathrm{~g}, 0.23 \mathrm{mmol})$ and $\mathrm{PMe}_{2} \mathrm{Ph}(0.056 \mathrm{~g}, 0.40 \mathrm{mmol})$ were dissolved in $15 \mathrm{~mL}$ of toluene and allowed irradiation at $254-350 \mathrm{~nm}$ for $1 \mathrm{~h}$ at room temperature. The colour of the reaction mixture changed from yellow to orange. Then the solvent was evaporated in vacuum; residue was extracted into hexane $/ \mathrm{CH}_{2} \mathrm{Cl}_{2}(70: 30 \mathrm{v} / \mathrm{v})$ and passed through Celite. After the removal of solvent from filtrate, the residue was subjected to chromatographic workup using silica-gel TLC plates. Elution with hexane $/ \mathrm{CH}_{2} \mathrm{Cl}_{2}(70: 30 \mathrm{v} / \mathrm{v})$ yielded yellow solid $\mathbf{4 b}(0.040 \mathrm{~g}, 23 \%)$.

4b: HRMS (ESI ${ }^{+}$): $m / z$ calculated for $\left[\mathrm{C}_{32} \mathrm{H}_{30} \mathrm{MnN}_{3} \mathrm{O}_{2} \mathrm{~S}_{2} \mathrm{P}_{2}+\mathrm{H}\right]^{+} 670.0713$, found 670.0735; ${ }^{1} \mathrm{H}$ NMR 
(500 MHz, $\left.\mathrm{CDCl}_{3}, 22{ }^{\circ} \mathrm{C}\right): \delta=7.61-6.98(\mathrm{~m}, 18 \mathrm{H}, \mathrm{Ph}), 1.57 \mathrm{ppm}\left(\mathrm{s}, 12 \mathrm{H}, \mathrm{CH}_{3}\right) ;{ }^{13} \mathrm{C}\left\{{ }^{1} \mathrm{H}\right\} \mathrm{NMR}(125$ $\left.\mathrm{MHz}, \mathrm{CDCl}_{3}, 22^{\circ} \mathrm{C}\right): \delta=169.9(\mathrm{~s}, \mathrm{C}=\mathrm{N}), 153.3,146.7(\mathrm{~s}, \mathrm{CN}), 138.0(\mathrm{~s}, \mathrm{CS}), 132.6-114.8 \mathrm{ppm}(\mathrm{s}$, bbza), $15.4 \mathrm{ppm}$ (s, Me); ${ }^{31} \mathrm{P}\left\{{ }^{1} \mathrm{H}\right\}$ NMR $\left(202 \mathrm{MHz}, \mathrm{CDCl}_{3}, 22{ }^{\circ} \mathrm{C}\right): \delta=35.6 \mathrm{ppm}$; IR $\left(\mathrm{CH}_{2} \mathrm{Cl}_{2}\right)$ : vbar $=1925,1848 \mathrm{~cm}^{-1}(\mathrm{CO})$.

\subsection{Synthesis of $\mathbf{5 a}, \mathbf{5 b}$ and $\mathbf{5 c}$ :}

In a flame-dried Schlenk tube, complex $3(0.100 \mathrm{~g}, 0.23 \mathrm{mmol})$ and ${ }^{\mathrm{BuNC}}(0.068 \mathrm{~g}, 0.92$ $\mathrm{mmol}$ ) were dissolved in $15 \mathrm{~mL}$ of toluene and allowed irradiation at $254-350 \mathrm{~nm}$ for $30 \mathrm{~min}$ at room temperature. The colour of the reaction mixture changed from yellow to orange. Then the solvent was evaporated in vacuum; residue was extracted into hexane/ $\mathrm{CH}_{2} \mathrm{Cl}_{2}(70: 30 \mathrm{v} / \mathrm{v})$ and passed through Celite. After the removal of solvent from filtrate, the residue was subjected to chromatographic workup using silica-gel TLC plates. Elution with hexane $/ \mathrm{CH}_{2} \mathrm{Cl}_{2}(70: 30 \mathrm{v} / \mathrm{v})$ yielded yellow solid $\mathbf{5 a}$ (0.036 g, 24\%) and orange solids $5 \mathbf{b}$ and $\mathbf{5 c}(0.023 \mathrm{~g}, 19 \%)$ [15].

5a. HRMS (ESI $\left.{ }^{+}\right): m / z$ calculated for $\left[\mathrm{C}_{21} \mathrm{H}_{21} \mathrm{BMnN}_{4} \mathrm{O}_{2} \mathrm{~S}_{2}+\mathrm{H}\right]^{+} 491.0582$, found $491.0582 ;{ }^{11} \mathrm{~B}\left\{{ }^{1} \mathrm{H}\right\}$ $\operatorname{NMR}\left(160 \mathrm{MHz}, \mathrm{CDCl}_{3}, 22{ }^{\circ} \mathrm{C}\right): \delta=19.8 \mathrm{ppm} ;{ }^{1} \mathrm{H}$ NMR $\left(500 \mathrm{MHz}, \mathrm{CDCl}_{3}, 22{ }^{\circ} \mathrm{C}\right): \delta=8.43-7.30$ (m, 8H, Ph), $4.75\left(\mathrm{br}, 1 \mathrm{H}, \mathrm{BH}_{\mathrm{t}}\right), 1.38\left(\mathrm{~s}, 9 \mathrm{H}, \mathrm{CMe}_{3}\right),-8.79$ and $-12.37 \mathrm{ppm}(\mathrm{br}, 2 \mathrm{H}, \mathrm{Mn}-\mathrm{H}-\mathrm{B}) ;{ }^{13} \mathrm{C}\left\{{ }^{1} \mathrm{H}\right\}$ $\operatorname{NMR}\left(125 \mathrm{MHz}, \mathrm{CDCl}_{3}, 22{ }^{\circ} \mathrm{C}\right): \delta=169.9(\mathrm{~s}, \mathrm{C}=\mathrm{N}), 151.0,146.8(\mathrm{~s}, \mathrm{CN}), 139.5(\mathrm{~s}, \mathrm{CS}), 127.0-$ 113.6 (s, bbza), $41.3(\mathrm{~s}, \mathrm{CMe}), 30.8 \mathrm{ppm}(\mathrm{s}, \mathrm{CMe})$; IR $\left(\mathrm{CH}_{2} \mathrm{Cl}_{2}\right)$ : vbar $=2306\left(\mathrm{BH}_{\mathrm{t}}\right), 2138\left(\mathrm{BH}_{\mathrm{b}}\right)$, $1969,1902 \mathrm{~cm}^{-1}(\mathrm{CO})$.

5b and 5c. HRMS $\left(\mathrm{ESI}^{+}\right): m / z$ calculated for $\left[\mathrm{C}_{25} \mathrm{H}_{30} \mathrm{BMnN}_{5} \mathrm{OS}_{2}+\mathrm{H}\right]^{+}$546.1369, found 546.1365; ${ }^{11} \mathrm{~B}\left\{{ }^{1} \mathrm{H}\right\}$ NMR $\left(160 \mathrm{MHz}, \mathrm{CDCl}_{3}, 22^{\circ} \mathrm{C}\right): \delta=19.4$ and $16.4 \mathrm{ppm} ;{ }^{1} \mathrm{H}$ NMR $\left(500 \mathrm{MHz}, \mathrm{CDCl}_{3}, 22^{\circ} \mathrm{C}\right)$ : $\delta=7.87-7.48(\mathrm{~m}, 8 \mathrm{H}, \mathrm{Ph}), 4.52\left(\mathrm{br}, 2 \mathrm{H}, \mathrm{BH}_{\mathrm{t}}\right), 1.38$ and $1.37\left(\mathrm{~s}, 18 \mathrm{H}, 2 \mathrm{CMe}_{3}\right),-7.62$ and $-11.95 \mathrm{ppm}$ (br, 4H, Mn-H-B); ${ }^{13} \mathrm{C}\left\{{ }^{1} \mathrm{H}\right\}$ NMR (125 MHz, $\left.\mathrm{CDCl}_{3}, 22{ }^{\circ} \mathrm{C}\right): \delta=166.2(\mathrm{~s}, \mathrm{C}=\mathrm{N}), 149.1,(\mathrm{~s}, \mathrm{CN})$, 132.8 (s, CS), 126.1-121.0 (s, bbza), $56.9\left(\mathrm{~s}, \mathrm{CMe}_{3}\right), 31.7,31.3 \mathrm{ppm}\left(\mathrm{s}, \mathrm{CMe}_{3}\right) ; \mathrm{IR}\left(\mathrm{CH}_{2} \mathrm{Cl}_{2}\right): v b a r=$ $2345\left(\mathrm{BH}_{\mathrm{t}}\right), 2114,2039\left(\mathrm{BH}_{\mathrm{b}}\right), 1882 \mathrm{~cm}^{-1}(\mathrm{CO})$.

\subsection{Synthesis of 7 :}

In a flame-dried Schlenk tube, borate complex $\left[\mathrm{Mn}(\mathrm{CO})_{3}\left\{\kappa^{3}-\mathrm{S}, \mathrm{S}^{\prime}, \mathrm{H}-\mathrm{H}_{2} \mathrm{~B}(\mathrm{mbz})_{2}\right\}\right], 6(0.100 \mathrm{~g}$, $0.206 \mathrm{mmol})$ and $\mathrm{PPh}_{3}(0.059 \mathrm{~g}, 0.23 \mathrm{mmol})$ were dissolved in $15 \mathrm{~mL}$ of toluene and allowed irradiation for $2 \mathrm{~h}$ at room temperature. Then the solvent was evaporated in vacuum; residue was extracted into hexane/ $\mathrm{CH}_{2} \mathrm{Cl}_{2}(70: 30 \mathrm{v} / \mathrm{v})$ and passed through Celite. After the removal of solvent 
from filtrate, the residue was subjected to chromatographic workup using silica-gel TLC plates. Elution with hexane/ $\mathrm{CH}_{2} \mathrm{Cl}_{2}(25: 75 \mathrm{v} / \mathrm{v})$ yielded red solid 7 (0.042 g, 28\%).

7. $\mathrm{HRMS}\left(\mathrm{ESI}^{+}\right): \mathrm{m} / z$ calculated for $\left[\mathrm{C}_{34} \mathrm{H}_{25} \mathrm{BMnN}_{2} \mathrm{O}_{2} \mathrm{PS}_{4}+\mathrm{Na}\right]^{+} 740.9908$, found $740.9892 ;{ }^{11} \mathrm{~B}\left\{{ }^{1} \mathrm{H}\right\}$ $\operatorname{NMR}\left(160 \mathrm{MHz}, \mathrm{CDCl}_{3}, 22{ }^{\circ} \mathrm{C}\right): \delta=19.5 \mathrm{ppm} ;{ }^{1} \mathrm{H} \mathrm{NMR}\left(500 \mathrm{MHz}, \mathrm{CDCl}_{3}, 22^{\circ} \mathrm{C}\right): \delta=7.82(\mathrm{~d}, J=$ $7.6 \mathrm{~Hz}, 1 \mathrm{H}), 7.72$ (q, $J=7.4 \mathrm{~Hz}, 2 \mathrm{H}), 7.64$ (d, $J=8.2 \mathrm{~Hz}, 2 \mathrm{H}), 7.59$ (d, $J=7.8 \mathrm{~Hz}, 2 \mathrm{H}), 7.51$ (t, $J=$ $7.6 \mathrm{~Hz}, 5 \mathrm{H}), 7.40(\mathrm{~m}, 5 \mathrm{H}), 7.33(\mathrm{~m}, 6 \mathrm{H}), 4.27$ (br, 1H, BH $),-9.67 \mathrm{ppm}(\mathrm{br}, 1 \mathrm{H}, \mathrm{Mn}-\mathrm{H}-\mathrm{B}) ;{ }^{31} \mathrm{P}\left\{{ }^{1} \mathrm{H}\right\}$ NMR (202 MHz, $\left.\mathrm{CDCl}_{3}, 22{ }^{\circ} \mathrm{C}\right): \delta=8.4 \mathrm{ppm}$; IR $\left(\mathrm{KBr}, \mathrm{v}, \mathrm{cm}^{-1}\right): 2468\left(\mathrm{~B}-\mathrm{H}_{\mathrm{t}}\right), 1949$ (CO).

\section{X-ray Structure Determination:}

Crystallographic information for compounds $2, \mathbf{4 a}, \mathbf{4 b}$ and 7 are described below. Crystal diffraction data for $\mathbf{2}$ and 4a were collected and integrated using a D8 VENTURE Bruker AXS diffractometer with multilayers monochromated $\mathrm{Mo}_{\alpha} \mathrm{K}_{\alpha}(\lambda=0.71073 \AA)$ radiation either at $150 \mathrm{~K}$ or room temperature. Crystal diffraction data of 7 was collected and integrated using a Bruker P4 diffractometer, with monochromated Mo- $\mathrm{K}_{\alpha}(\lambda=0.71073 \AA)$ radiation at $100 \mathrm{~K}$ and $\mathbf{4 b}$ was collected and integrated using a Bruker AXS Kappa APEX2 CCD diffractometer equipped with graphite monochromated Mo- $\mathrm{K}_{\alpha}(\lambda=0.71073 \AA)$ radiation at room temperature. The structures were solved by direct methods using SIR92 [16] or via a dual-space algorithm using the SHELXT program [17] and refined using SHELXL-2014 [18].

Crystal data for 2: CCDC: $1886985, \mathrm{C}_{23} \mathrm{H}_{15} \mathrm{~N}_{4} \mathrm{O}_{3} \mathrm{ReS}_{2}, M_{\mathrm{r}}=645.71$, triclinic, space group $P-1, a=$ 9.2634(8) $\AA, b=11.4125(11) \AA, c=11.7015(11) \AA, \alpha=72.699(3)^{\circ}, \beta=82.107(3)^{\circ}, \gamma=81.844(3)^{\circ}$, $V=1163.21(19) \AA^{3}, Z=2, \rho_{\text {calcd }}=1.844 \mathrm{~g} \mathrm{~cm}^{-3}, \mu=5.436 \mathrm{~mm}^{-1}, F(000)=624, R_{1}=0.0199, w R_{2}=$ $0.0622,5320$ independent reflections $\left[2 \theta \leq 54.97^{\circ}\right]$ and 299 parameters.

Crystal data for 4a: CCDC: $1886987, \mathrm{C}_{42} \mathrm{H}_{34} \mathrm{MnN}_{3} \mathrm{O}_{2} \mathrm{P}_{2} \mathrm{~S}_{2}, M_{\mathrm{r}}=793.72$, monoclinic, space group $P 2_{1} / c, a=20.7461(5) \AA, b=11.1107(2) \AA, c=17.0743(4) \AA, \alpha=90^{\circ}, \beta=101.0060(10)^{\circ}, \gamma=90^{\circ}, V$ $=3863.30(15) \AA^{3}, Z=4, \rho_{\text {calcd }}=1.365 \mathrm{~g} \mathrm{~cm}^{-3}, \mu=0.573 \mathrm{~mm}^{-1}, F(000)=1640, R_{1}=0.0339, w R_{2}=$ $0.0923,6811$ independent reflections $\left[2 \theta \leq 55.72^{\circ}\right]$ and 471 parameters.

Crystal data for $4 \mathbf{b}$ : CCDC: $1886986, \mathrm{C}_{32} \mathrm{H}_{30} \mathrm{MnN}_{3} \mathrm{O}_{2} \mathrm{P}_{2} \mathrm{~S}_{2}, M_{\mathrm{r}}=669.59$, monoclinic, space group $P 2_{1} / c, a=17.4469(14) \AA, b=13.9261(12) \AA, c=12.8197(13) \AA, \alpha=90^{\circ}, \beta=94.068(3)^{\circ}, \gamma=90^{\circ}, V$ $=3106.9(5) \AA^{3}, Z=4, \rho_{\text {calcd }}=1.431 \mathrm{~g} \mathrm{~cm}^{-3}, \mu=0.697 \mathrm{~mm}^{-1}, F(000)=1384, R_{1}=0.0273, w R_{2}=$ $0.0710,7120$ independent reflections $\left[2 \theta \leq 54.964^{\circ}\right]$ and 383 parameters. 
Crystal data for 7: CCDC 1835499, $\mathrm{C}_{34} \mathrm{H}_{25} \mathrm{BMnS}_{4} \mathrm{~N}_{2} \mathrm{PO}_{2}, M_{\mathrm{r}}=803.44$, triclinic, $P-1, a=9.6544(8)$ $\AA, b=12.5732(12) \AA, c=16.3798(14) \AA, \alpha=90.565(3)^{\circ}, \beta=107.043(3)^{\circ}, \gamma=111.498(3)^{\circ}, V=$ $1753.3(3) \AA^{3}, Z=2, \rho_{\text {calcd }}=1.522 \mathrm{mg} / \mathrm{m}^{3}, \mu=0.849 \mathrm{~mm}^{-1}, F(000)=820, R_{1}=0.0563, w R_{2}=0.1058$, 8039 independent reflections $\left[2 \theta \leq 54.968^{\circ}\right], 439$ parameters.

\section{Results and Discussion}

\subsection{Reactivity of $\operatorname{Re}_{2}(\mathrm{CO})_{10}$ with $\mathrm{Na}\left[\left(\mathrm{H}_{3} \mathrm{~B}\right)\right.$ bbza] ligand:}

The chemistry of metal complexes containing $f a c-\mathrm{M}(\mathrm{CO})_{3}\left(\mathrm{M}=\mathrm{Re}\right.$ or $\left.{ }^{99 \mathrm{~m}} \mathrm{Tc}\right)$ has extensively been studied as radioactive probe for targeting brain 5- $\mathrm{HT}_{1 \mathrm{~A}}$ serotonergic receptors by Santos et al. [4e]. In order to synthesize similar type of borate complexes of group-7 transition metals, earlier we have investigated the reaction of trihydrobis(benzothiazol-2-yl)amideborate, $\mathrm{Na}\left[\left(\mathrm{H}_{3} \mathrm{~B}\right)\right.$ bbza] with $\mathrm{M}_{2}(\mathrm{CO})_{10}(\mathrm{M}=\mathrm{Mn}$ or $\mathrm{Re})[11]$. In case of manganese, the reaction led to the formation of bis $(\sigma)$ borate complex $\left[\mathrm{Mn}(\mathrm{CO})_{3}(\mu-\mathrm{H})_{2} \mathrm{BHNCSC}_{6} \mathrm{H}_{4}(\mathrm{NR})\right], 3\left(\mathrm{R}=\mathrm{NCSC}_{6} \mathrm{H}_{4}\right)$, whereas, the reaction with $\mathrm{Re}_{2}(\mathrm{CO})_{10}$ yielded octahedral complex $\left[\mathrm{Re}(\mathrm{CO})_{2}\left(\mathrm{~N}_{3} \mathrm{C}_{2} \mathrm{~S}_{2} \mathrm{C}_{12} \mathrm{H}_{8}\right)_{2}\right], \mathbf{1}$ [11]. As we failed to isolate the bis $(\sigma)$ borate complex of rhenium, we revisited this reaction under different conditions. As a result, we have isolated another compound $\mathbf{2}$ in very less yield along with known compound $\mathbf{1}$ (Scheme 1).

Compound 2 was isolated by thin layer chromatographic (TLC) separation. This compound was characterized by limited spectroscopic data in combination with mass spectrometric and single crystal X-ray diffraction data. The ${ }^{1} \mathrm{H}$ NMR spectrum shows a peak at $\delta=4.04 \mathrm{ppm}$ for the methyl protons. Infrared spectrosocpic data confirms the presence of both bbza ligand and carbonyl ligands.

The mass spectrum of 2 showed a molecular ion peak at $m / z 647.0[\mathrm{M}+\mathrm{H}]^{+}$. Consistent with the spectroscopic data, the authenticity of $\mathbf{2}$ was confirmed by X-ray crystallographic analysis. The solidstate X-ray structure of 2, shown in Figure 2, shows that the central metal rhenium is in distorted
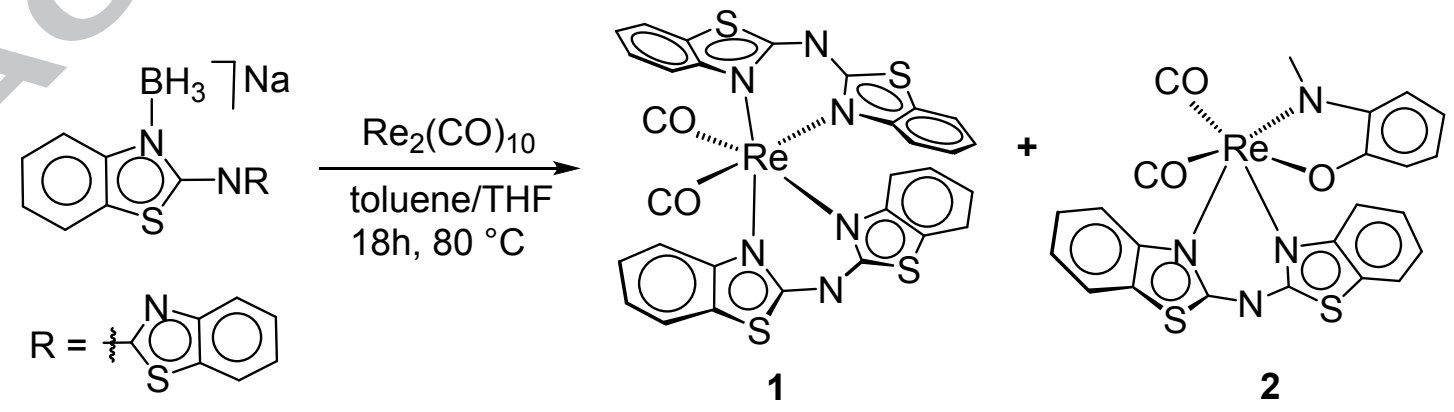

Scheme 1. Synthesis of compounds 1 and 2. 
octahedral environment and resides $0.013 \AA$ far from the mean plane of $\{\mathrm{N} 1-\mathrm{O} 3-\mathrm{C} 22-\mathrm{C} 23\}$ and comparable to the cis-[ $\left.\mathrm{ReO}_{2}(\mathrm{Hdab})(\mathrm{py})_{2}\right](\mathbf{1})\left(\mathrm{H}_{2} \mathrm{dab}=1,2\right.$-diaminobenzene) [19]. Complex 2 is an example of neutral hexacoordinate rhenium complex with a cis arrangement of the two carbonyl ligands. We believe that the sources of oxygen and methyl group in $\mathbf{2}$ might be the carbonyl ligand.

\subsection{Reactivity of Mn-bis( $\sigma)$ borate, 3 with phosphine ligands}

Having failed to isolate the bis $(\sigma)$ borate of rhenium, we have moved our attention to synthesise manganese bis $(\sigma)$ borate complexes. In our earlier report, we have demonstrated the reaction of $\left[\mathrm{Mn}(\mathrm{CO})_{3}(\mu-\mathrm{H})_{2} \mathrm{BHNCSC}_{6} \mathrm{H}_{4}(\mathrm{NR})\right], 3$ with $\mathrm{PL}_{2} \mathrm{~L}^{\prime}\left(\mathrm{L}=\mathrm{Ph}\right.$ or $\left.\mathrm{L}^{\prime}=\mathrm{Me}\right)$ and that yielded the isomeric bis $(\sigma)$ borate complexes $\left[\mathrm{Mn}(\mu-\mathrm{H})_{2}\left(\mathrm{BHNCSC}_{6} \mathrm{H}_{4}\right)\{\mathrm{NR}\}(\mathrm{CO})_{2} \mathrm{PL}_{2} \mathrm{~L}^{\prime}\right]$ and $\left[\mathrm{Mn}(\mu-\mathrm{H})_{2} \mathrm{BHN}(\mathrm{NCS}-\right.$ $\left.\left.\mathrm{C}_{6} \mathrm{H}_{4}\right) \mathrm{R}(\mathrm{CO})_{2} \mathrm{PL}_{2} \mathrm{~L}^{\prime}\right]\left(\mathrm{L}=\mathrm{Ph}, \mathrm{L}^{\prime}=\mathrm{Ph}\right.$ or Me; $\left.\mathrm{R}=\mathrm{NCSC}_{6} \mathrm{H}_{4}\right)$. In order to check the lability of the metal-carbon bond in $\mathbf{3}$, we carried out the reaction with phosphine ligands, which are strong $\sigma$-donors and comparatively poor $\pi$-acceptors. Therefore, room temperature photolysis of $\mathbf{3}$ with excess amount of phosphine ligands was investigated and that yielded manganese-phosphine complexes $\left[\mathrm{Mn}(\mathrm{CO})_{2}\left(\mathrm{PL}_{2} \mathrm{~L}^{\prime}\right)_{2}\left\{\mathrm{~N}\left(\mathrm{C}_{7} \mathrm{H}_{4} \mathrm{NS}\right)_{2}\right\}\right],\left(\mathbf{4 a}: \mathrm{L}=\mathrm{Ph}, \mathrm{L}^{\prime}=\mathrm{Me}, \mathbf{4 b}: \mathrm{L}=\mathrm{Me}, \mathrm{L}^{\prime}=\mathrm{Ph}\right)($ Scheme 2$)$. Both the

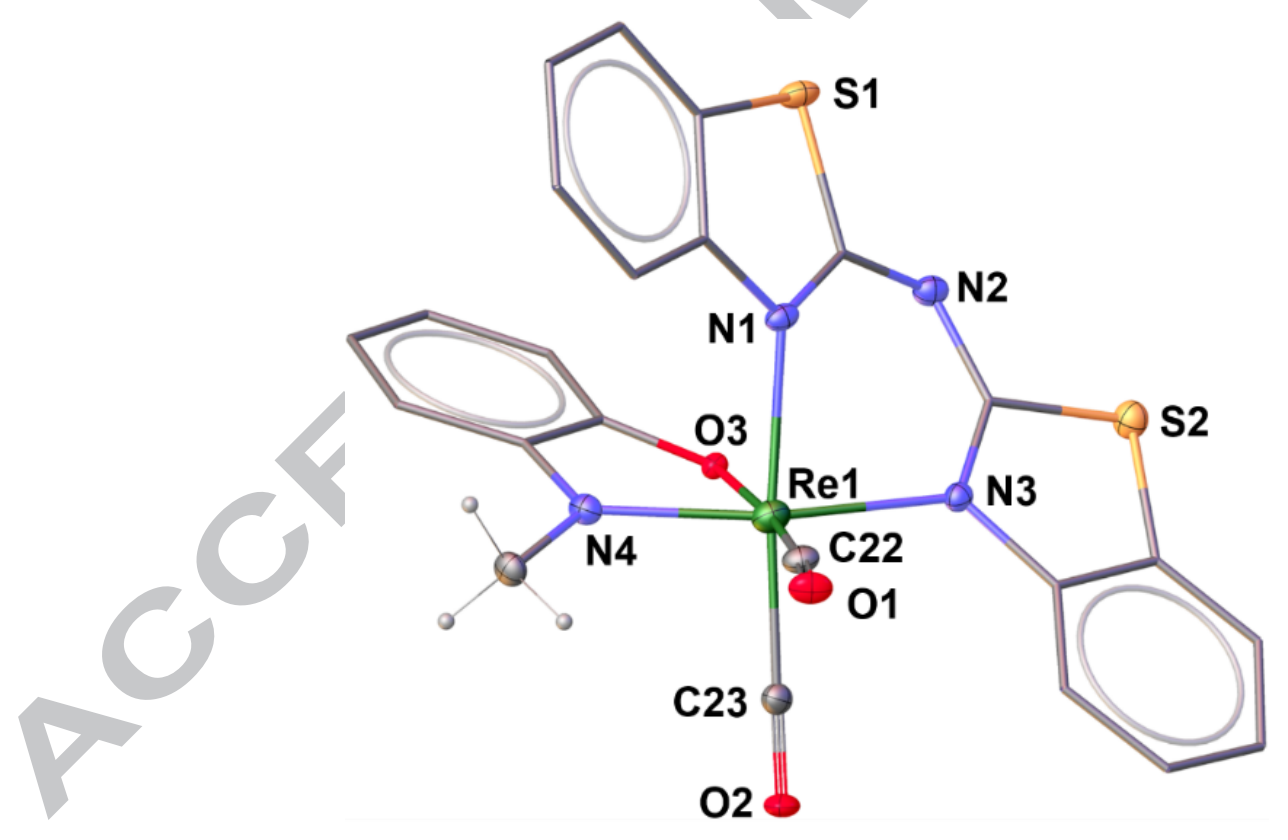

Figure 2. Molecular structure of compound $\mathbf{1}$ in the solid state. All hydrogen atoms (except on methyl units) have been removed for clarity. Selected bond lengths $(\AA)$ and bond angles $\left(^{\circ}\right)$ : Re1-C23 1.960(3), Re1-O3 2.106(2), Re1-N3 2.114(3), Re1-N1 2.129(3); N4-Re1-O3 77.84(10). 
compounds were isolated in good yields and were separated using thin layer chromatographic technique and characterized by multi-nuclear NMR and IR spectroscopy, mass spectrometry and Xray diffraction studies. Note that, no ${ }^{11} \mathrm{~B}$ chemical shift was observed for both $4 \mathbf{a}$ and $\mathbf{4 b}$ in the ${ }^{11} \mathrm{~B}\left\{{ }^{1} \mathrm{H}\right\}$ NMR spectra and that confirmed the absence of boron in these compounds. The mass spectrometric analysis of $\mathbf{4 a}$ and $\mathbf{4 b}$ shows molecular ion peaks at $\mathrm{m} / \mathrm{z} 794.1038$ and 670.0735 respectively. On the other hand, the ${ }^{1} \mathrm{H}$ NMR spectra of $\mathbf{4 a}$ and $\mathbf{4 b}$ showed chemical shifts for protons present in bbza ligand, phenyl and the methyl groups. The ${ }^{31} \mathrm{P}\left\{{ }^{1} \mathrm{H}\right\}$ NMR spectra showed the chemical shifts at $\delta=$ 50.7 and $35.6 \mathrm{ppm}$ for compounds $\mathbf{4 a}$ and $\mathbf{4 b}$, respectively. In addition to this, the IR spectra confirmed the presence of $\mathrm{CO}$ ligands in both the compounds. The identity of compounds $4 \mathbf{a}$ and $\mathbf{4 b}$ were finaly confirmed by X-ray diffraction analysis.

X-ray quality crystals of both $\mathbf{4 a}$ and $\mathbf{4 b}$ were obtained from the slow evaporation of hexane and $\mathrm{CH}_{2} \mathrm{Cl}_{2}$ mixture at $-5{ }^{\circ} \mathrm{C}$. The solid state $\mathrm{X}$-ray structures of them shown in Figure 3, clearly show that one of the $\mathrm{CO}$ ligands is replaced by a phosphine and another unit of a phosphine ligand coordinated to the metal centre by replacing the borate unit. The average Mn-P bond length (2.2997 $\AA)$ in $\mathbf{4 a}$ and $\mathbf{4 b}$ is comparable to that in $\left[\mathrm{Mn}(\mathrm{CO})_{4}\left(\mathrm{PPhMe}_{2}\right)\left(\mathrm{BH}_{2} \cdot \mathrm{PMe}_{3}\right)\right](2.302(1) \AA)$ [20] and longer than that in the manganese bis $(\sigma)$ borate complexes $\left[\mathrm{Mn}(\mu-\mathrm{H})_{2}\left(\mathrm{BHNCSC}_{6} \mathrm{H}_{4}\right)\{\mathrm{NR}\}(\mathrm{CO})_{2}\right.$ $\left.\mathrm{PL}_{2} \mathrm{~L}^{\prime}\right]\left(\mathrm{L}=\mathrm{Ph}, \mathrm{L}^{\prime}=\mathrm{Ph}\right.$ or Me; $\left.\mathrm{R}=\mathrm{NCSC}_{6} \mathrm{H}_{4}\right)(2.257 \AA)$ [11]. However, the distances between $\mathrm{Mn}$ and $\mathrm{C}$ in 4a (Mn1-C7 2.539(2) $\AA$ ) and 4b (Mn1-C27 2.5289(14) $\AA$ ) are in the higher range of manganese-carbon single bond distance [21]. These apparent bonds are a result of the very close proximity of the two centers ( $\mathrm{Mn}$ and $\mathrm{C}$ ), due to the $\mathrm{NN}$ chelation. Phosphine $\left(\mathrm{PR}_{3}\right)$ show an important role in coordination and organometallic chemistry because of their wide range of coordination [2228]. Many of metal phosphine complexes used as catalysts [29, 30]. In adition, transition-metal-

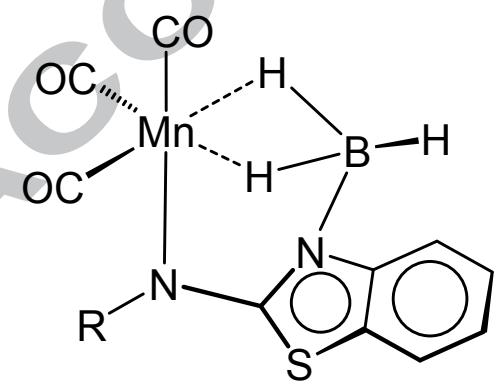

3

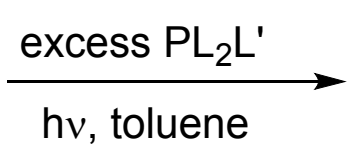

$\mathrm{rt}, 1 \mathrm{~h}$

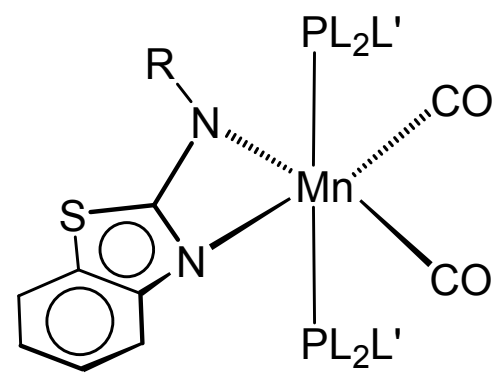

4a: $L=P h, L^{\prime}=M e$

4b: $L=M e, L^{\prime}=P h$

Scheme 2. Reactivity of compound 3 with phosphines. 
phosphine complexes can activate small molecules, such as $\mathrm{H}_{2}, \mathrm{~N}_{2}, \mathrm{O}_{2}, \mathrm{H}_{2} \mathrm{O}$ and $\mathrm{CO}_{2}$ etc. So, complexes $\mathbf{4 a}$ and $\mathbf{4 b}$ certainly a good entry in the list of transition-metal-phosphine complexes.

Computational studies of $4 \boldsymbol{a}$ and $\mathbf{4 b}$ : In order to know the nature of metal to ligand coordination, we have performed the DFT calculations at BP86/Def2-SVP level, starting from the coordinates obtained from the X-ray structure [31]. A quick look into the molecular orbitals of 4a suggests that the electron density at HOMO is located at manganese, carbonyl ligands and mostly on benzothiazole moiety. The LUMO is located at manganese, one phenyl ring of $\mathrm{PPh}_{2} \mathrm{Me}$ and benzothiazole moiety (Figure S25). The HOMO-LUMO energy gap is about $2.48 \mathrm{eV}$, which is lesser than its parent molecule $\mathbf{3}(2.95 \mathrm{eV})$ that infers the stability of $\mathbf{4 a}$. In case of $\mathbf{4 b}$ the electron density in HOMO is mainly located at manganese and carbonyl ligands whereas LUMO is located mainly at benzothiazole moiety (Figure S26). The HOMO-LUMO energy gap ( $2.52 \mathrm{eV})$ is almost similar to that of compound $\mathbf{4 a}$. This might confer comparable thermodynamic stability of $\mathbf{4 a}$ and $\mathbf{4 b}$.
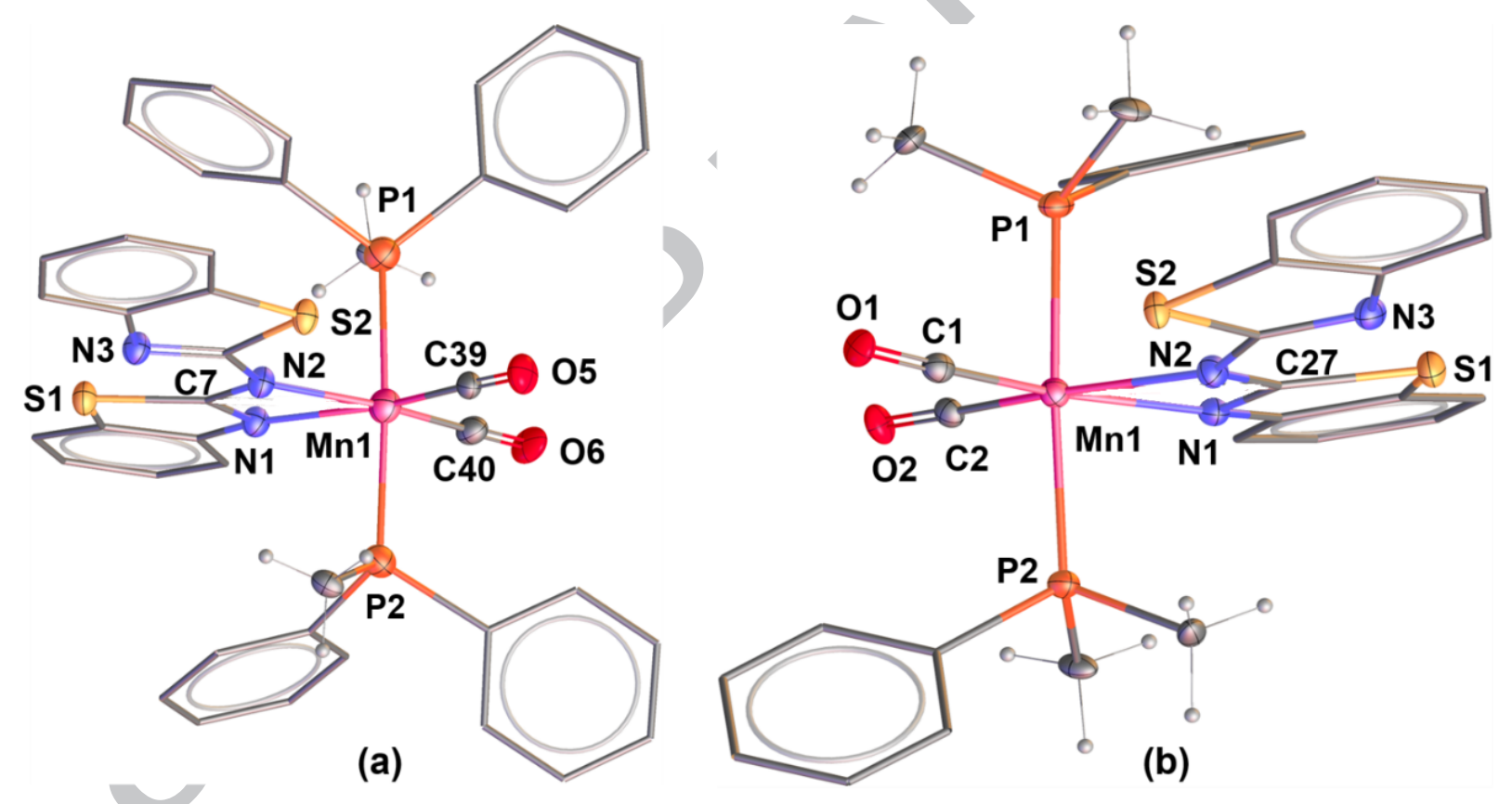

Figure 3. Molecular structure of compounds $\mathbf{4 a}$ and $\mathbf{4 b}$ in the solid state. All hydrogen atoms (except on methyl units) have been removed for clarity. Selected bond lengths $(\AA)$ and bond angles $\left(^{\circ}\right)$ of $4 \mathbf{a}$ (a): Mn1-P1 2.3121(7), Mn1-P2 2.2899(7), Mn1-N2 2.1013(18), C40-Mn1 1.764(3), C39-Mn1 1.771(2), N1-C7-Mn1 56.58(11), N2-C7-Mn1 55.76(11), S1-C7-Mn1 172.52(13), C40-Mn1-C39 93.00(11); 4b (b) Mn1-P1 2.2904(4), Mn1-P2 2.3066(4), Mn1-N1 2.0782(12), Mn1-N2 2.1186(13), C2-Mn1-C1 90.12(7), P1-Mn1-P2 175.713(16). 


\subsection{Reactivity of Mn-bis( $\sigma)$ borate, 3 with ${ }^{t} B u N C$}

Isocyanide ligands are strong $\sigma$-donors and comparatively poor $\pi$-acceptors [27]. Therefore, to study the labile nature of manganese carbonyl bond, we treated $\mathbf{3}$ with excess amount of ${ }^{t} \mathrm{BuNC}$. As shown in Scheme 3, treatment of $\mathbf{3}$ with ${ }^{t} \mathrm{BuNC}$ yielded the bis $(\sigma)$ borate complexes of manganese $\left[\mathrm{Mn}(\mu-\mathrm{H})_{2}\left(\mathrm{BHNCSC}_{6} \mathrm{H}_{4}\right)(\mathrm{NR})(\mathrm{CO})_{\mathrm{x}} \mathrm{L}_{\mathrm{y}}\right], \mathbf{5 a}-\mathbf{b}\left(\mathbf{5 a}: \mathrm{x}=2, \mathrm{y}=1 ; \mathbf{5 b}: \mathrm{x}=1 ; \mathrm{y}=2 ; \mathrm{L}={ }^{t} \mathrm{BuNC} ; \mathrm{R}=\right.$ $\left.\mathrm{NCSC}_{6} \mathrm{H}_{4}\right)$ and $\left[\mathrm{Mn}(\mu-\mathrm{H})_{2} \mathrm{BH}\left\{\mathrm{N}\left(\mathrm{NCSC}_{6} \mathrm{H}_{4}\right)_{2}\right\}(\mathrm{CO})\left({ }^{(} \mathrm{BuNC}\right)_{2}\right]$, 5c. The ${ }^{11} \mathrm{~B}\left\{{ }^{1} \mathrm{H}\right\}$ chemical shift of compound $5 \mathbf{a}$ appeared at the downfield region $(\delta=19.8 \mathrm{ppm})$ as compared to the starting material, $3(\delta=17.3 \mathrm{ppm})$. Compound 5a displayed ${ }^{1} \mathrm{H}$ NMR resonances at $\delta=4.75 \mathrm{ppm}$ and $\delta=1.38 \mathrm{ppm}$ due to terminal $\mathrm{BH}$ and ${ }^{t} \mathrm{Bu}$ protons, respectively. In addition, peaks at $\delta=-8.79$ and $-12.37 \mathrm{ppm}$ in 1:1 ratio, were assigned for the bridging $\mathrm{Mn}-\mathrm{H}-\mathrm{B}$ protons. High resolution mass spectrometry experiment was carried out for $\mathbf{5 a}$ and the result provided molecular mass consistent with the formula $\mathrm{C}_{21} \mathrm{H}_{21} \mathrm{BMnN}_{4} \mathrm{O}_{2} \mathrm{~S}_{2}$. Based on the spectroscopic assignment of the 5a, the molecular formula of $\mathbf{5 a}$ is $\left[\mathrm{Mn}(\mu-\mathrm{H})_{2}\left(\mathrm{BHNCSC}_{6} \mathrm{H}_{4}\right)(\mathrm{NR})(\mathrm{CO})_{2}\left({ }^{(} \mathrm{BuNC}\right)\right]\left(\mathrm{R}=\mathrm{NCSC}_{6} \mathrm{H}_{4}\right)$ in which a ${ }^{t} \mathrm{BuNC}$ group replaced one of the carbonyl ligands of compound $\mathbf{3}$.

Note that compounds $\mathbf{5 b}$ and $\mathbf{5} \mathbf{c}$ were inseparable orange solids and our repeated attempts to isolate $\mathbf{5 b}$ and $\mathbf{5 c}$ in pure form met with no success. Hence, they have been characterized using combined spectroscopic data. The ${ }^{11} \mathrm{~B}\left\{{ }^{1} \mathrm{H}\right\}$ chemical shifts of compounds $\mathbf{5 b}$ and $\mathbf{5} \mathbf{c}$ are close to each other $(\delta=19.4$ and $16.4 \mathrm{ppm})$. The ${ }^{1} \mathrm{H}$ NMR chemical shifts confirm the presence of two ${ }^{t} \mathrm{Bu}$ groups, two Mn-H-B protons and one terminal B-H proton for both the compounds. High resolution mass spectrometry experiment carried out on $\mathbf{5 b}$ and $\mathbf{5 c}$ provided molecular mass consistent with the formula $\mathrm{C}_{25} \mathrm{H}_{30} \mathrm{BMnN}_{5} \mathrm{OS}_{2}$. All our efforts to grow the crystals for $\mathbf{5 a - c}$ were futile and the molecular formulae were predicted based on the spectroscopic data in combination with mass spectrometric data.<smiles></smiles>

3

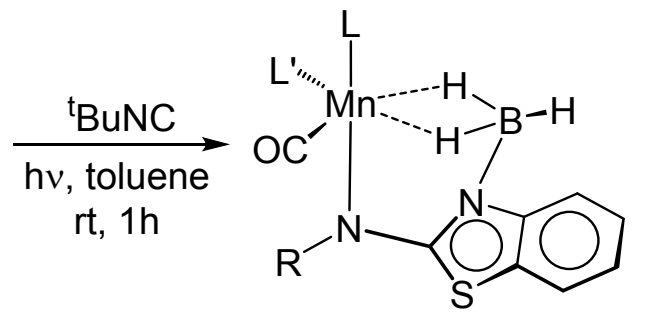

5a: $L={ }^{t} B u N C ; L^{\prime}=C O$

5b: $L=L^{\prime}={ }^{t}$ BuNC

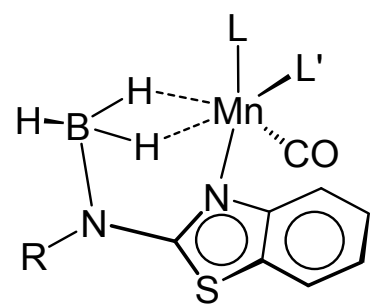

5c: $L=L^{\prime}={ }^{t}$ BuNC 
Scheme 3. Reactivity of compound 3 with ${ }^{t}$ BuNC.

Therefore, the molecular formula for $\mathbf{5 b}$ and $\mathbf{5 c}$ assigned as $\left[\mathrm{Mn}(\mu-\mathrm{H})_{2}\left(\mathrm{BHNCSC}_{6} \mathrm{H}_{4}\right)(\mathrm{NR})(\mathrm{CO})-\right.$ $\left.\left({ }^{t} \mathrm{BuNC}\right)_{2}\right], \mathbf{5 b}\left(\mathrm{R}=\mathrm{NCSC}_{6} \mathrm{H}_{4}\right)$ and $\left[\mathrm{Mn}(\mu-\mathrm{H})_{2} \mathrm{BH}\left\{\mathrm{N}\left(\mathrm{NCSC}_{6} \mathrm{H}_{4}\right)_{2}\right\}-(\mathrm{CO})\left({ }^{t} \mathrm{BuNC}\right)_{2}\right], \mathbf{5} \mathbf{c}$.

Compounds $\mathbf{5 b}$ and $\mathbf{5} \mathbf{c}$ can be called as isomers by considering the molecular formula, geometry and ${ }^{11} \mathrm{~B}$ chemical shift values. Similar kind of behavior was observed when 8 -aminoquinoline and 2aminopyridine ligands were treated with group-8 metal precursors [30]. Thus, the formation of $\mathbf{5 b}$ and 5c might have happened due to the reverse translocation of the bbza ligand between Mn and boron atom. Although there are some cases that are known, formation of such type of complexes are unusual. For example, $\left[\mathrm{Os}\left\{\mathrm{B}(\mathrm{OEt})\left(\mathrm{NC}_{5} \mathrm{H}_{4} \mathrm{NH}\right)\right\} \mathrm{Cl}(\mathrm{CO})\left(\mathrm{PPh}_{3}\right)_{2}\right]$ vs $\left[\mathrm{Os}\left\{\mathrm{BCl}\left(\mathrm{NHC}_{5} \mathrm{H}_{4} \mathrm{~N}\right)\right\} \mathrm{Cl}(\mathrm{CO})-\left(\mathrm{PPh}_{3}\right)_{2}\right]$ and $\left[\mathrm{Os}\left\{\mathrm{B}(\mathrm{OEt}) \mathrm{NHC}_{9} \mathrm{H}_{6} \mathrm{~N}\right\} \mathrm{Cl}(\mathrm{CO})\left(\mathrm{PPh}_{3}\right)_{2}\right]$ vs $\left[\mathrm{Os}\left(\mathrm{BNHC}_{9} \mathrm{H}_{6} \mathrm{~N}\right) \mathrm{Cl}_{2}(\mathrm{CO})\left(\mathrm{PPh}_{3}\right)_{2}\right]$ [31]. The nature of the bonding for compounds $\mathbf{5 b}$ and $\mathbf{5 c}$ are somewhat comparable to the known complexes, $[\mathrm{Mn}(\mu$ $\left.\mathrm{H})_{2}\left(\mathrm{BHNCSC}_{6} \mathrm{H}_{4}\right)\{\mathrm{NR}\}(\mathrm{CO})_{2}\left(\mathrm{PL}_{2} \mathrm{~L}^{\prime}\right)\right]$ vs $\left[\mathrm{Mn}(\mu-\mathrm{H})_{2}\left\{\mathrm{BHN}\left(\mathrm{NCSC}_{6} \mathrm{H}_{4}\right) \mathrm{R}\right\}(\mathrm{CO})_{2}\left(\mathrm{PL}_{2} \mathrm{~L}^{\prime}\right)\right](\mathrm{R}=\mathrm{NCS}-$ $\mathrm{C}_{6} \mathrm{H}_{4}, \mathrm{~L}=\mathrm{L}^{\prime}=\mathrm{Ph}$, or $\left.\mathrm{L}=\mathrm{Ph}, \mathrm{L}^{\prime}=\mathrm{Me}\right)[11]$ and $\left[\left(\eta^{4}-\mathrm{COD}\right) \mathrm{Rh}(\mu-\mathrm{H}) \mathrm{BHRh}\left(\mathrm{C}_{14} \mathrm{H}_{8} \mathrm{~N}_{3} \mathrm{~S}_{2}\right)_{3}\right][9 h]$. One of the interesting bonding features of $\mathbf{5 b}$ and $\mathbf{5 c}$ is the coordination modes of the central metal as well as the boron atom. In $\mathbf{5 b}$, the bonding of boron is similar to that of $\mathbf{3}$. The only difference between the geometry of $\mathbf{3}$ and $\mathbf{5 b}$ is the presence of a ${ }^{t} \mathrm{BuNC}$ ligand instead of CO. In contrast, the boron atom in 5c is bonded to the exocyclic nitrogen of the bbza unit, whereas Mn atom is coordinated to the endocyclic nitrogen.

\subsection{Reactivity of Mn-borate complex 6 with $\mathrm{PPh}_{3}$}

In order to check the lability of the $\mathrm{CO}$ ligands at 6 , we treated it with $\mathrm{PPh}_{3}$ ligand under photolytic condition that yielded borate complex $\left[\mathrm{Mn}\left(\mathrm{CO}_{2}\right)\left\{\kappa^{3}-\mathrm{S}, \mathrm{S}^{\prime}, \mathrm{H}-\mathrm{H}_{2} \mathrm{~B}(\mathrm{mbz})_{2}\right\}\left(\mathrm{PPh}_{3}\right)\right], 7$ (Scheme 4). This compound was isolated as red solid by thin layer chromatographic (TLC) technique. The ${ }^{11} \mathrm{~B}\left\{{ }^{1} \mathrm{H}\right\}$ NMR spectrum of 7 shows sharp signal at $\delta=19.5 \mathrm{ppm}$. The ${ }^{1} \mathrm{H}$ NMR spectrum showed upfield resonances at $\delta=-9.67 \mathrm{ppm}$, which has been assigned to $\mathrm{Mn}-\mathrm{H}_{\mathrm{b}}-\mathrm{B}$ proton and the peak at $\delta=4.27$ ppm has been assigned for $\mathrm{B}-\mathrm{H}_{\mathrm{t}}$ proton. The ${ }^{31} \mathrm{P}\left\{{ }^{1} \mathrm{H}\right\}$ NMR exhibits singlet at $\delta=8.4$ ppm that confirms the presence of phosphine ligand. The IR spectrum show stretching frequencies, characteristics of $\mathrm{B}-\mathrm{H}_{\mathrm{t}}$ and $\mathrm{CO}$ ligands at 2468 and $1949 \mathrm{~cm}^{-1}$ respectively.

Suitable crystals were obtained by recrystallizing the prepared complex in hexane and $\mathrm{CH}_{2} \mathrm{Cl}_{2}$ mixture at $-5{ }^{\circ} \mathrm{C}$. The molecular structure of complex 7 was unambiguously determined by single 


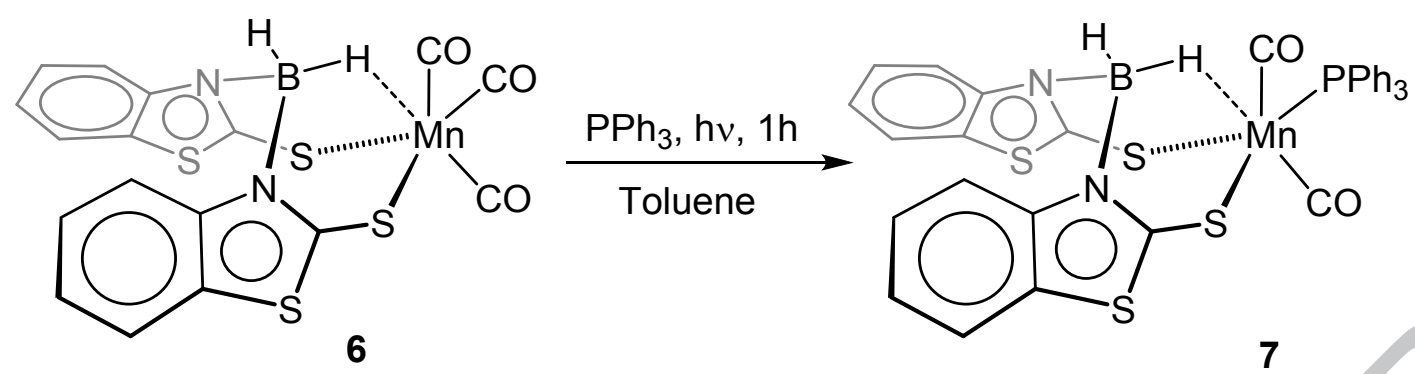

Scheme 4. Reactivity of complex 6 with $\mathrm{PPh}_{3}$

crystal X-ray crystallography (Figure 4). The crystals of 7 contain one molecule in their asymmetric unit cell. The solid state X-ray structure of 7 demonstrates that one of the CO ligands trans to $\mathrm{Mn} \cdots \mathrm{H}-$ $\mathrm{B}$ interaction in 7 has been replaced by $\mathrm{PPh}_{3}$ ligand. The borate ligand in 7 adopts a tridentate coordination mode, similar to parent compound $\mathbf{6}$. The only difference between the geometries of 6 and 7 is the presence of a $\mathrm{PPh}_{3}$ ligand instead of CO ligand. The bond distances of $\mathrm{Mn}-\mathrm{B}$ and $\mathrm{Mn} \cdots \mathrm{H}-\mathrm{B}$ in 7 (2.687(3) and 1.74(3) Å respectively) are comparable with that of parent compound 6 (2.699 and

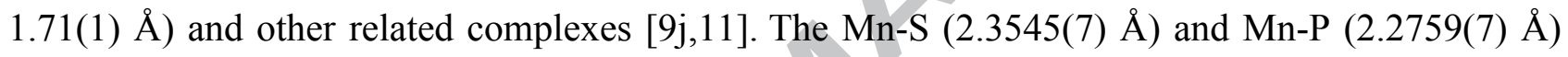
bond distances are within the range $[9 \mathrm{j}, 11]$.

Computational studies of Mn borate complex, 7: In order to know the nature of the metal to ligand coordination, we have performed the DFT calculations at BP86/Def2-SVP level [32], starting from the coordinates attained from the X-ray structure. A quick look into the molecular orbitals of 7

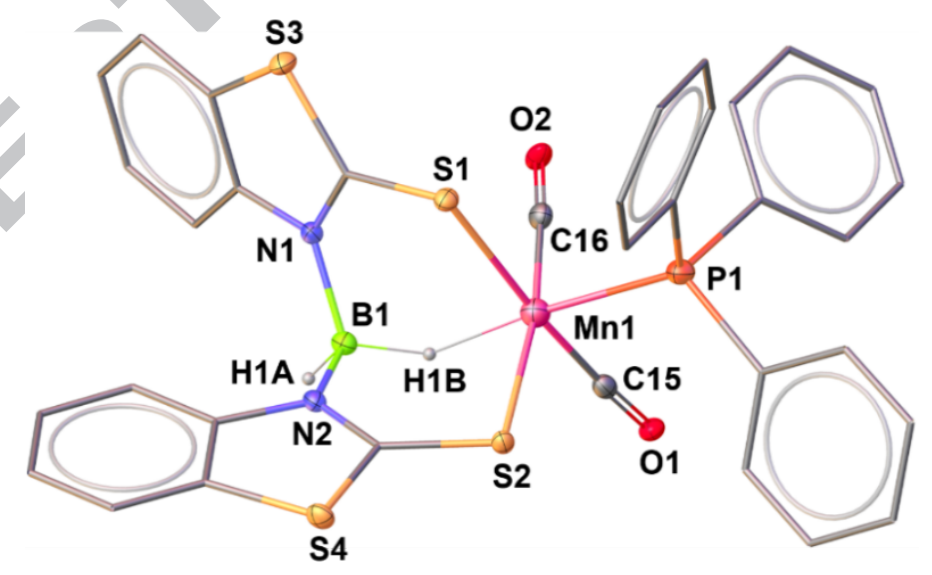

Figure 4. Molecular structure of compound 7 in the solid state. All hydrogen atoms have been removed for clarity. Selected bond lengths (Å): Mn1-B1 2.687(3), Mn1-H1B 1.74(3), Mn1-P1 2.2759(7), B1-H1B 1.19(3), B1-H1A 1.10(3), Mn1-S1 2.4295(7), B1-N1 1.561(3), B1-N2 1.554(3). 
suggests that the electron density at HOMO is located at manganese and carbonyl ligands whereas the LUMO is located on both manganese and one of the benzothiazole moieties of the borate ligand (Figure S25). The HOMO-LUMO gap for 7 is about $1.98 \mathrm{eV}$ less than that of parent compound 6 $(2.17 \mathrm{eV})$. From the NBO based second order perturbation analysis, the donor-acceptor interaction from the filled $\sigma(\mathrm{B}-\mathrm{H})$ orbitals to vacant orbitals of the manganese, the stabilizing energy of 82.33 $\mathrm{kcal} \mathrm{mole}^{-1}$ and the back donation of $30.12 \mathrm{kcal} \mathrm{mole}^{-1}$ were observed (Figure 5). The WBI's (Wiberg bond index) of compound 7 are comparable with those of 6.
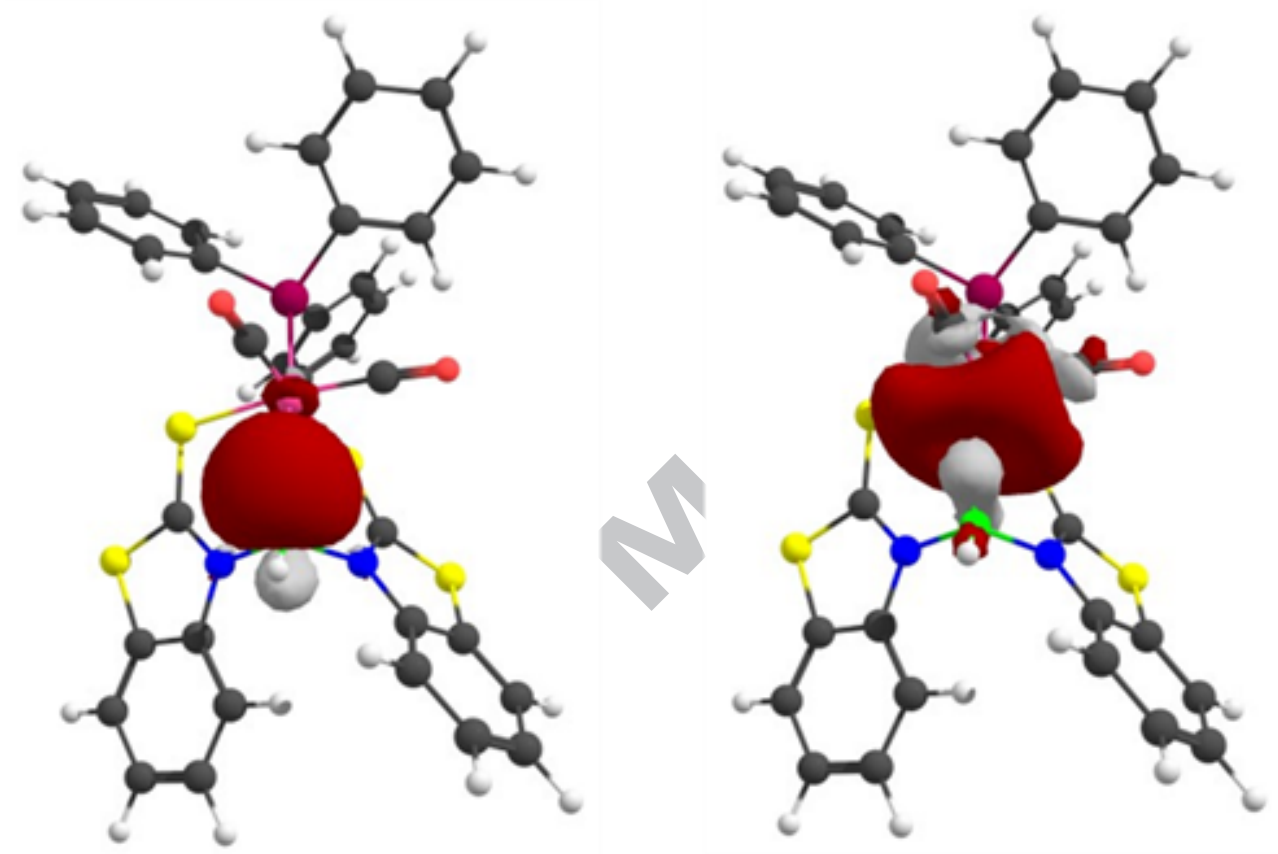

Figure 5. MOs responsible for $\sigma_{(\mathrm{B}-\mathrm{H})} \rightarrow \mathrm{Mn}$ interaction in 7 obtained from NBO analysis (contour value: $\left.\pm 0.03\left[\mathrm{e} / \mathrm{bohr}^{3}\right]^{1 / 2}\right)$.

\section{Conclusions}

In conclusion, we have described the synthesis and characterization of the rhenium complex containing bbza ligand. In addition, we have explored the reactivity of bis $(\sigma)$ borate and borate complexes of manganese with different tertiary phosphines and isocyanide ligand. The reaction of manganese bis $(\sigma)$ borate complex with excess phosphines led to the formation of manganese phosphine complexes. In contrast, the reaction with isocyanide ligand yielded ${ }^{t} \mathrm{BuNC}$-substituted bis $(\sigma)$ borate complexes of manganese. Reactivity of these borate complexes with other ligands are currently under investigation. 


\section{Acknowledgements}

The authors acknowledge the Council of Scientific \& Industrial Research (CSIR) (Project No. 01(2939)/18/emr-ii), New Delhi, India for financial support. C. N. thank Department of Science and Technology, DST-INSPIRE for research fellowship. K. S. and S. G. are thankful to Council of Scientific and Industrial Research (CSIR) and IIT Madras, respectively, for their research fellowships. IIT Madras is gratefully acknowledged for computational facilities.

\section{Appendix A. Supplementary data}

CCDC 1886985 (2), 1886987 (4a), 1886986 (4b) and 1835499 (7) contain the supplementary crystallographic data for this paper. These data can be obtained free of charge via http://www.ccdc.cam.ac.uk/conts/retrieving.html, or from the Cambridge Crystallographic Data Centre, 12 Union Road, Cambridge CB2 1EZ, UK; fax: (+44) 1223-336-033; or e-mail: deposit@ccdc.cam.ac.uk. Supplementary data associated with this article can be found, in the online version, at http://dx.doi.org

\section{References}

[1] (a) H.V.R. Dias, W. Jin, Inorg. Chem. 35 (1996) 3687; (b) A. Adach, J. Coord. Chem. 70 (2017) 757;

(c) M. Pellei, G.G. Lobbia, G. Papini, C. Santini, Mini Rev. Org. Chem. 7 (2010) 173; (d) C. Santini, M. Marinelli, M. Pellei, Eur. J. Inorg. Chem. (2016) 2312.

[2] L.F. Soares, D.C. Menezes, R.M. Silva, A.C. Doriguetto, J. Ellena, Y.P. Mascarenhas, E.E.Castellano, Polyhedron 23 (2004) 205.

[3] (a) S. Trofimenko, J. Am. Chem. Soc. 88 (1966) 1842; (b) S. Trofimenko, Scorpionates: The Coordination of Poly(pyrazolyl)-borate Ligands, Imperial College Press, London, 1999; (c) S. Trofimenko, Chem. Rev. 93 (1993) 943; (d) C. Pettinari, Scorpionates II: Chelating Borate Ligands, Imperial College Press, London, 2008; (e) M. Imran, B. Neumann, H. G. Stammler, U. Monkowius, M. Ertl, N. W. Mitzel, Dalton Trans. 43 (2014) 1267.

[4] (a) F. Tisato, C. Bolzati, A. Duatti, G. Bandoli, F. Refosco, Inorg. Chem. 32 (1993) 2042; (b) M. Videira, C. Moura, A. Datta, A. Paulo, I. C. Santos, I. Santos, Inog. Chem. 48 (2009) 4251; (c) C. S. Masui, J. M. Mayer, Inorg. Chim. Acta 251 (1996) 325; (d) M. Videira, L. Maria, A. Paulo, I. C. Santos, I. Santos, P. D. Vaz, M. J. Calhorda, Organometallics 27 (2008) 1334; (e) L, Maria, A. Paulo, I. C. Santos, I. Santos, P. Kurz, B. Spingler, R. Alberto, J. Am. Chem. Soc. 128 (2006) 14590; (f) J. 
Brugos, J. A. Cabeza, P. G. Álvarez, E. P. Carreño, J. F. V. Maelen, Dalton Trans. 46 (2017) 4009; (g) M.J. Abrams, A. Davison and A.G. Jones, Inorg. Chim. Acta, 82 (1984) 125.

[5] S. Schlecht, J. F. Hartwig, J. Am. Chem. Soc. 122 (2000) 9435.

[6] T. Kakizawa, Y. Kawano, and M. Shimoi, Organometallics. 20 (2001) 3213.

[7] (a) L. A. Graham, A. R. Fout, K. R. Kuehne, J. L. White, B. Mookherji, F. M. Marks, G. P. A. Yap, L. N. Zakharov, A. L. Rheingold, D. Rabinovich, Dalton Trans. (2005) 171; (b) A. H. Ilkhechi, S. L. Guo, M. Bolte, M. Wagner, Dalton Trans. (2003) 2303; (c) F. Hossain, M. A. Rigsby, C. T. Duncan, P. L. Milligan, Jr., R. L. Lord; M. H. Baik, F. A. Schultz, Inorg. Chem 46 (2007).2596.

[8] A. P. Forshaw, J. M. Smith, A. Ozarowski, J. Krzystek, D. Smirnov, S. A. Zvyagin, T. D. Harris, H. I. Karunadasa, J. M. Zadrozny, A. Schnegg, K. Holldack, T. A. Jackson, A. Alamiri, D. M. Barnes, J. Telser, Inorg. Chem 52 (2013).144; (b) S. V. Kolotilov, A. W. Addison, S. Trofimenko, W. Dougherty, V. V. Pavlishchuk, Inorg. Chem. Commun. 7 (2004) 485.

[9] (a) R. S. Anju, D. K. Roy, B. Mondal, K. Yuvaraj, C. Arivazhagan, K. Saha, B. Varghese, S. Ghosh, Angew. Chem., Int. Ed. 53 (2014) 2873; (b) D. K. Roy, A. De, S. Panda, B. Varghese, S. Ghosh, Chem. Eur. J. 21 (2015) 13732; (c) D. K. Roy, R. Borthakur, S. Bhattacharyya, V. Ramkumar, S. Ghosh, J. Organomet. Chem. 799-800 (2015) 132; (d) R. Ramalakshmi, K. Saha, D. K. Roy, B. Varghese, A. K. Phukan, S. Ghosh, Chem. Eur. J. 21 (2015) 17191; (e) D. K. Roy, B. Mondal, R. S. Anju and S. Ghosh, Chem. Eur. J. 21 (2015) 3640; (f) K. Saha, B. Joseph, R. Ramalakshmi, R. S. Anju, B. Varghese, S. Ghosh, Chem. Eur. J. 22 (2016) 7871; (g) B. Mondal, R. Borthakur, S. Ghosh, In Organometallic Chemistry and Catalysis of Transition Metal-Borane Compounds; World Scientific, Imperial College Press Ltd. (UK), 2018; (h) K. Saha, R. Ramalakshmi, R. Borthakur, S. Gomosta, K. Pathak, V. Dorcet, T. Roisnel, J.-F. Halet, S. Ghosh, Chem. Eur. J. 23 (2017) 18264; (i) K. Saha, B. Joseph, R. Borthakur, R. Ramalakshmi, T. Roisnel, S. Ghosh, Polyhedron 125 (2017) 246; (j) K. Saha, S. Gomosta, R. Ramalakshmi, B. Varghese, S. Ghosh, Proc. Natl. Acad. Sci., India, Sect. A Phys. Sci. 86 (2016) 521; (k) K. Saha, U. Kaur, S. Kar, B. Mondal, B Joseph, P.K.S. Antharjanam, S. Ghosh, Inorg. Chem. (2019).

[10] (a) H. Vahrenkamp, Acc. Chem. Res. 32 (1999) 589; (b) C. Kimblin, B. M. Bridgewater, T. Hascall, G. Parkin, J. Chem. Soc., Dalton Trans. (2000) 891; (c) C. Slugovc, I. Padilla-Martinez, S. Sirol, E. Carmona, Coord. Chem. Rev. 213 (2001) 129; (d) M.D. Spicer, J. Reglinski, Eur. J. Inorg. Chem. (2009) 1553; (e) M.M. Morlok, K.E. Janak, G. Zhu, D.A. Quarless, G. Parkin, J. Am. Chem. Soc. 127 (2005) 14039; (f) S. Bakbak, VK. Bhatia, C.D. Incarvito, A.L. Rheingold, D. Rabinovich, Polyhedron 20 (2001) 3343; (g) G. Alcaraz, S. Sabo-Etienne, Angew. Chem., Int. Ed. 2010, 49, 7170; (h) R.C. da Costa, B.W. 
Rawe, A. Iannetelli, G.J. Tizzard, S.J. Coles, A.J. Guwy, G.R. Owen, Inorg. Chem. 58 (2019) 359; (i) A. Kumar, N.A. Beattie, S.D. Pike, S.A. Macgregor, A.S. Weller, Angew. Chem., Int. Ed. 55 (2016) 6651; (j) G. Bouhadir, D. Bourissou, Coordination of Lewis Acids to Transition Metals: Z-Type Ligands, Springer, Heidelberg, 2016; (k) H. Braunschweig, R.D. Dewhurst, A. Schneider, Chem. Rev. 110 (2010) 3924.

[11] K. Saha, R. Ramalakshmi, S. Gomosta, K. Pathak, V. Dorcet, T. Roisnel, J.-F. Halet, S. Ghosh, Chem. Eur. J. 23 (2017) 9812.

[12] D.R. Dauer, M. Flügge, R.H. Irmer, D. Stalke, Dalton Trans. 45 (2016) 6136.

[13] G.E. Ryschkewitsch, K.C. Nainan, Inorg. Synth. 15 (1974) 113.

[14] Due to low yield of compound 2, the ${ }^{1} \mathrm{H}$ and ${ }^{13} \mathrm{C}\left\{{ }^{1} \mathrm{H}\right\}$ NMR spectra are not impressive and the spectroscopic assignments for compound $\mathbf{2}$ are not reported here.

[15] The total yields of $\mathbf{5 b}$ and $\mathbf{5} \mathbf{c}$ were $\sim 19 \%$; these two compounds were not analytically pure.

[16] A. Altomare, G. Cascarano, C. Giacovazzo, A. Guagliardi, M.C. Burla, G. Polidori, M. Camalli, J. Appl. Cryst. 27 (1994) 435.

[17] G.M. Sheldrick, Acta Cryst. A71 (2015) 3.

[18] G.M. Sheldrick, Acta Cryst. C71 (2015) 3.

[19] G. Bandoli, A. Dolmella, T.I.A. Gerbe, D. Luzipo, J.G.H. du Preez, Inorg. Chim. Acta 325 (2001) 215.

[20] T. Yasue, Y. Kawano, M. Shimoi, Angew. Chem., Int. Ed. 42 (2003) 1727.

[21] R.M. Meier, T.P. Hanusa, Structural Organomanganese Chemistry in PATAI'S Chemistry of Functional Groups (2011) John Wiley \& Sons, Ltd.

[22] G. Wilkinson, R.D. Gillard, J.A. McCleverty (Eds.), Comprehensive Coordination Chemistry, Pergamon Press, Oxford, 1987.

[23] J.A. McCleverty, T.J. Meyer (Eds.), Comprehensive Coordination Chemistry II, Elsevier, Oxford, 2004.

[24] C.A. McAuliffe, W. Levason, Phosphine, Arsine and Stibine Complexes of the Transition Elements, Elsevier, Amsterdam, 1979.

[25] G.O. Spessard, G.L. Miessler, Organometallic Chemistry, Prentice-Hall, Upper Saddle River, NJ, 1997. 
[26] R.H. Crabtree, The Organometallic Chemistry of the Transition Metals, 5th ed., John Wiley and Sons, 2009.

[27] N. Fey, A.G. Orpen, J.N. Harvey, Coord. Chem. Rev. 253 (2009) 704.

[28] (a) P.W.N.M. van Leeuwen, Homogeneous Catalysis Understanding the Art, Kluwer Academic Publishers, Dordrecht, 2004;(b) R.H. Crabtree, The Organometallic Chemistry of the Transition Metals, fourth ed., John Wiley \& Sons, 2005; (c) W. Tolman, Activation of Small Molecules: Organometallic and Bioinorganic Perspectives, Wiley-VCH, Weinheim, 2006.

[29] (a) J.G.J. Raj, Rev. Inorg. Chem. 35 (2015) 25; (b) C. D. Swor, D. R. Tyler, Coord. Chem. Rev. 255 (2011) 2860.

[30] A. Phanopoulos, N.J. Long, P.W. Miller, Triphosphine Ligands: Coordination Chemistry and Recent Catalytic Applications, Struct. Bonding (Berlin, Ger.) 171 (2016) 141.

[31] (a) C.E.F. Rickard, W.R. Roper, A. Williamson, L.J. Wright, Organometallics 21 (2002) 4862; (b) G.J. Irvine, C.E.F. Rickard, W.R. Roper, A. Williamson, L.J. Wright, Angew. Chem., Int. Ed. 39 (2000) 948.

[32] Geometry optimization was performed at the BP86/Def2-SVP level of theory. For full details see Supporting Information. 
Fine tuning of reactivity and structure of bis( $\sigma)$ borate and borate complexes of manganese by systematic ligand variation

Chandan Nandi ${ }^{\mathrm{a}}$,Koushik Saha ${ }^{\mathrm{a}}$, Suman Gomosta ${ }^{\mathrm{a}}$, Vincent Dorcet ${ }^{\mathrm{b}}$, Sundargopal Ghosh ${ }^{\mathrm{a}, *}$

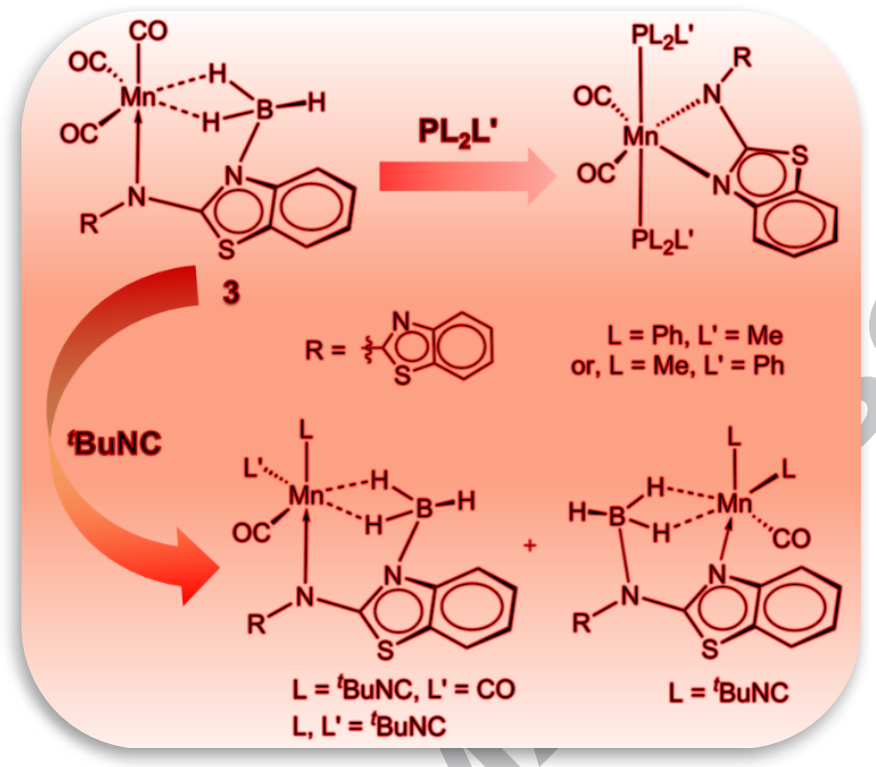

Photolysis of a manganese bis $(\sigma)$ borate complex, 3 with excess of phosphines yielded manganese phosphine complexes. In contrast, photolysis of $\mathbf{3}$ with ${ }^{t} \mathrm{BuNC}$ yielded mono/bis $\left({ }^{\mathrm{t}} \mathrm{BuNC}\right)$-substituted manganese borate complexes (see picture).

\section{Fine tuning of reactivity and structure of bis( $\sigma)$ borate and borate complexes of manganese by systematic ligand variation}

Chandan Nandia ${ }^{\mathrm{a}}$ Koushik Saha ${ }^{\mathrm{a}}$, Suman Gomosta ${ }^{\mathrm{a}}$, Vincent Dorcet ${ }^{\mathrm{b}}$, Sundargopal Ghosha,*

Abstract: The complexes with $f a c-\left[\mathrm{M}(\mathrm{CO})_{3}\right]^{+}$units of group-7 metals are interesting synthons for the development of target-specific drugs. Therefore, thermolysis reaction of $\operatorname{Re}_{2}(\mathrm{CO})_{10}$ with various borate ligands have been investigated as a possible route to isolate bis $(\sigma)$ borate complexes of rhenium. The reaction of trihydrobis(benzothiazol-2-yl)amideborate, $\mathrm{Na}\left[\left(\mathrm{H}_{3} \mathrm{~B}\right)\right.$ bbza $]$ (bbza = bis(benzothiazol2-yl)amine) with $\operatorname{Re}_{2}(\mathrm{CO})_{10}$ led to the formation of distorted octahedral rhenium complexes $\left[(\mathrm{CO})_{2} \operatorname{Re}\left\{\mathrm{N}\left(\mathrm{C}_{7} \mathrm{H}_{4} \mathrm{NS}\right)_{2}\right\}_{2}\right], 1$ and $\left[(\mathrm{CO})_{2} \mathrm{Re}\left\{\mathrm{N}\left(\mathrm{C}_{7} \mathrm{H}_{4} \mathrm{NS}\right)_{2}\right\}\left\{\mathrm{C}_{6} \mathrm{H}_{4} \mathrm{~N}(\mathrm{Me}) \mathrm{O}\right\}\right], 2$. In order to increase the library of complexes conatining $f a c-\left\{\mathrm{M}(\mathrm{CO})_{3}\right\}^{+}$moieties as well as to check the lability of the metal-carbonyl bond, reactivity of manganese borate complexes $\left[\mathrm{Mn}(\mathrm{CO})_{3}(\mu-\mathrm{H})_{2} \mathrm{BHNCSC}_{6} \mathrm{H}_{4}(\mathrm{NR})\right]$, 
$3\left(\mathrm{R}=\mathrm{NCSC}_{6} \mathrm{H}_{4}\right)$ and $\left[\mathrm{Mn}(\mathrm{CO})_{3}\left\{\kappa^{3}-\mathrm{S}, \mathrm{S}^{\prime}, \mathrm{H}-\mathrm{H}_{2} \mathrm{~B}(\mathrm{mbz})_{2}\right\}\right], \mathbf{6}(\mathrm{mbz}=$ 2-mercapto-benzothiazolyl) with different ligands were carried out. Photolysis of 3 with excess phosphine ligands $\left(\mathrm{PPh}_{2} \mathrm{Me}\right.$ or $\mathrm{PMe} \mathrm{Ph}_{2} \mathrm{Ph}$

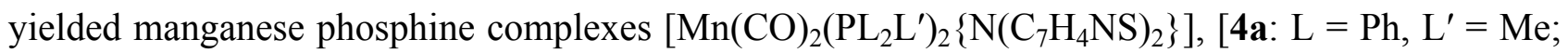
4b: $\left.\mathrm{L}=\mathrm{Me}, \mathrm{L}^{\prime}=\mathrm{Ph}\right]$. Interestingly, the reaction of 3 with ${ }^{t} \mathrm{BuNC}$ yielded mono/bis $\left({ }^{t} \mathrm{BuNC}\right)-$ substituted manganese borate complexes $\left[\mathrm{Mn}(\mu-\mathrm{H})_{2}\left(\mathrm{BHNCSC}_{6} \mathrm{H}_{4}\right)(\mathrm{NR})(\mathrm{CO})_{\mathrm{x}} \mathrm{L}_{\mathrm{y}}\right], \mathbf{5 a}-\mathbf{b}(\mathbf{5 a}: \mathbf{x}=2$, y $\left.=1 ; \mathbf{5 b}: \mathrm{x}=1 ; \mathrm{y}=2 ; \mathrm{L}={ }^{t} \mathrm{BuNC} ; \mathrm{R}=\mathrm{NCSC}_{6} \mathrm{H}_{4}\right)$ and $\left[\mathrm{Mn}(\mu-\mathrm{H})_{2} \mathrm{BH}\left\{\mathrm{N}\left(\mathrm{NCSC}_{6} \mathrm{H}_{4}\right)_{2}\right\}(\mathrm{CO})\left({ }^{t} \mathrm{BuNC}\right)_{2}\right]$, $\mathbf{5 c}$. Compounds $\mathbf{5 b}$ and $\mathbf{5 c}$ are structural isomers with a different coordination mode of the bbza ligand. Under similar reaction conditions, photolysis of 6 with $\mathrm{PPh}_{3}$ in toluene generated borate complex of manganese $\left[\mathrm{Mn}\left(\mathrm{CO}_{2}\right)\left\{\kappa^{3}-\mathrm{S}, \mathrm{S}^{\prime}, \mathrm{H}-\mathrm{H}_{2} \mathrm{~B}(\mathrm{mbz})_{2}\right\}\left(\mathrm{PPh}_{3}\right)\right]$, 7. All the compounds were characterised by multi-nuclear NMR, IR spectroscopy and mass spectrometry. Density functional theory (DFT) calculations were carried out to investigate the bonding and electronic structures of these compounds.

Keywords: Bis $(\sigma)$ borate, Manganese, Rhenium, Phosphine, ${ }^{t} \mathrm{BuNC}$

a Department of Chemistry, Indian Institute of Technology Madras, Chennai 600 036, India.
b Univ Rennes, CNRS, ISCR (Institut des Sciences Chimiques de Rennes) - UMR 6226, F-35000 Rennes, France.

*Corresponding Author. Phone: (+91) 442257 4230; Fax: (+91) 4422574202.

E-mail address: sghosh@iitm.ac.in

\section{Introduction}

In coordination chemistry, transition metal complexes containing borate ligands such as poly(pyrazolyl)borate, poly(methimazolyl)borate, poly(2-mercapto-thiazolyl)borate, earmarked a unique place due to their different chelation modes towards the transition metals [1-3]. Several examples of borate complexes of group 6-10 metals, especially with late transition metals, are known which are structurally characterized. The development of borate complexes of group- 7 metals have been explored intensively in the case of rhenium and technetium as compared with manganese [4]. In 2000, Hartwig first reported the $\sigma$-borane complexes of manganese followed by Shimoi in 2001 [56]. Later Wagner, Rabinovich, Peters and others reported manganese complexes of borate ligands containing various heterocyclic rings [7-8]. As shown in Figure 1, these borate ligands exhibit different types of coordination mode towards the metal centre. Subsequently, bis $(\sigma)$ borate complexes of Re and ${ }^{99 m} \mathrm{Tc}$, in which the ligand binds the metal centre in $\left(\kappa^{3}-\mathrm{H}, \mathrm{H}, \mathrm{S}\right)$ coordination mode, were 
synthesized and structurally characterized by Santos et al. The $f a c-\left[\operatorname{Re}\left\{\kappa^{3}-\mathrm{H}(\mu-\mathrm{H})_{2} \mathrm{~B}\left(\operatorname{tim}{ }^{\mathrm{Bupip}}\right)\right\}(\mathrm{CO})_{3}\right]$ (tim $^{\text {Bupip }}=1$-[4-((2-methoxyphenyl)-1-piperazinyl)butyl]-2-mercapto-imidazolyl) complex was found to be potential for the design of CNS receptor ligand radiopharmaceutical [4e].

There are very few examples of manganese borate complexes known in which the scorpionate ligands bind the metal centre in $\left(\kappa^{3}-\mathrm{E}, \mathrm{H}, \mathrm{H}\right)(\mathrm{E}=$ hetero atom) fashion. The foremost example of this type of complexes of manganese containing 2-(methylamido)pyridine-borane as a tripod $\left(\kappa^{3}-\mathrm{N}, \mathrm{H}, \mathrm{H}\right)$ ligand was synthesized and structurally characterized by Cabeza et al. We [9] and others [10] have recently reported several $\sigma$-borate complexes of early and late transition metals by developing a new synthetic route from $\left[\mathrm{Cp}^{*} \mathrm{MCl}_{2}\right]_{2}\left(\mathrm{M}=\mathrm{Ru}, \mathrm{Rh}\right.$ or Ir) and $\mathrm{Na}\left[\mathrm{H}_{2} \mathrm{~B}(\mathrm{mbz})_{2}\right][9,11]$. We have further demonstrated that these types of complexes of manganese containing $\left\{\mathrm{M}(\mathrm{CO})_{3}\right\}$ fragment can also be accessible using the transmetalation approach [9d,9j]. Successively, we have synthesized and structurally characterized a series of borate complexes of group 7 metals using various borate ligands those show a stronger preference for either the $\left(\kappa^{3}-\mathrm{H}, \mathrm{H}, \mathrm{N}\right)$ or $\left(\kappa^{3}-\mathrm{H}, \mathrm{S}, \mathrm{S}\right)$ coordination mode [11]. Therefore, the synthesis and reactivity of these borate complexes containing group-7 $\left\{\mathrm{M}(\mathrm{CO})_{3}\right\}$ fragment became of our particular interest. Herein, we describe the reactivity of bis $(\sigma)$ borate and borate complexes of manganese with different type of stronger $\sigma$-donor and weaker $\pi$-acceptor ligands such as, phosphines and ${ }^{t} \mathrm{BuNC}$ that generated different types of phosphine and bis $(\sigma)$ borate complexes of manganese, respectively.

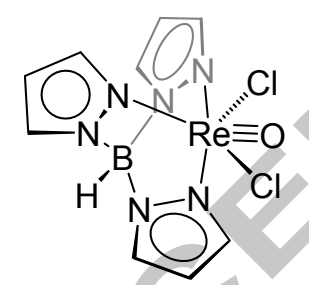

Davison, 1984

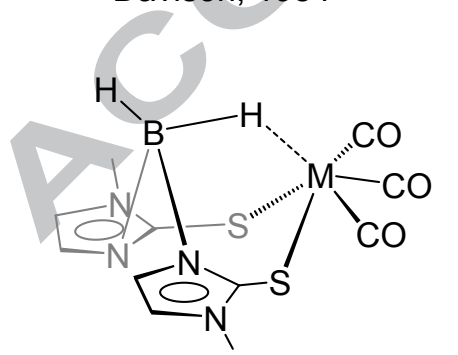

$M=M n ;$ Rabinovich, 2005

$M=R e ;$ Santos, 2009

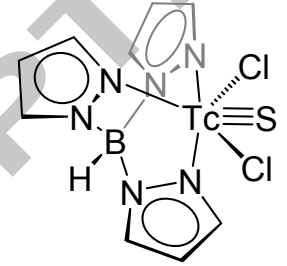

Tisato and Duatti, 1993

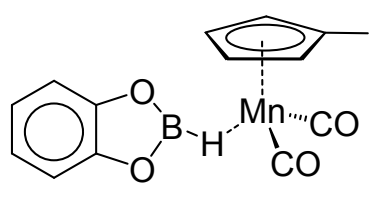

Hartwig, 2000

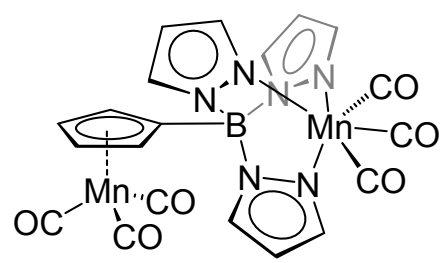

Wagner, 2003

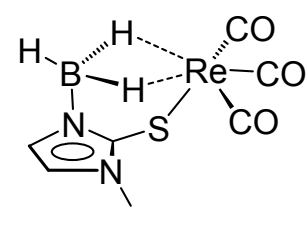

Santos, 2006

Figure 1. Various examples of borane/borate complexes of group 7 metals. 


\section{Experimental details}

\subsection{General methods and instrumentation:}

All of the syntheses were carried out under argon atmosphere with standard Schlenk line and glove box techniques. $\mathrm{Na}\left[\left(\mathrm{H}_{3} \mathrm{~B}\right)\right.$ bbza] [11,12], $\mathrm{Na}\left[\mathrm{H}_{2} \mathrm{~B}(\mathrm{mbz})_{2}\right.$ ] [3e], compounds 3 [11] and $\mathbf{6}$ [9j], were prepared according to literature methods and other chemicals $\mathrm{Re}_{2}(\mathrm{CO})_{10},{ }^{t} \mathrm{BuNC}, \mathrm{PPh}_{3}, \mathrm{PPh}_{2} \mathrm{Me}$ and $\mathrm{PMe}_{2} \mathrm{Ph}$ were obtained commercially. The external reference for the ${ }^{11} \mathrm{~B}\left\{{ }^{1} \mathrm{H}\right\} \mathrm{NMR}\left[\mathrm{Bu}_{4} \mathrm{~N}\right]\left[\mathrm{B}_{3} \mathrm{H}_{8}\right]$ [13] was synthesized according to literature method. Thin-layer chromatography was carried out on $250 \mathrm{~mm}$ diameter aluminum supported silica gel TLC plates. NMR spectra were recorded on a 500 $\mathrm{MHz}$ Bruker FT-NMR spectrometer. Residual solvent protons were used as reference $\left(\delta, \mathrm{CDCl}_{3}, 7.26\right.$ ppm), while a sealed tube containing $\left[\mathrm{Bu}_{4} \mathrm{~N}\right]\left[\mathrm{B}_{3} \mathrm{H}_{8}\right]$ in benzene- $d_{6}(\delta, \mathrm{ppm},-30.07)$ was used as an external reference for the ${ }^{11} \mathrm{~B}\left\{{ }^{1} \mathrm{H}\right\}$ NMR. Mass spectra were recorded on a BrukerMicroTOF-II mass spectrometer in ESI ionization mode. Infrared spectra were recorded on a JASCO FT/IR-4100 spectrometer. The photoreactions described in this report were conducted in a Luzchem LZC-4V photoreactor, with irradiation at 254-350 $\mathrm{nm}$.

\subsection{Synthesis of $\mathbf{2}$}

In a flame-dried Schlenk tube, a solution of $\operatorname{Re}_{2}(C O)_{10}(0.100 \mathrm{~g}, 0.15 \mathrm{mmol})$ in $10 \mathrm{~mL}$ of toluene was added to $10 \mathrm{~mL}$ of THF solution of $\mathrm{Na}\left[\left(\mathrm{H}_{3} \mathrm{~B}\right) \mathrm{bbza}\right](0.195 \mathrm{~g}, 0.60 \mathrm{mmol})$ and was heated for $18 \mathrm{~h}$ at $80{ }^{\circ} \mathrm{C}$. The color of the reaction mixture changed from colourless to pale green. The solvent was then evaporated in vacuum; residue was extracted into hexane $/ \mathrm{CH}_{2} \mathrm{Cl}_{2}(60: 40 \mathrm{v} / \mathrm{v})$ and passed through Celite. After removal of solvent from filtrate, the residue was subjected to chromatographic workup using silica-gel TLC plates. Elution with hexane/ $\mathrm{CH}_{2} \mathrm{Cl}_{2}(60: 40 \mathrm{v} / \mathrm{v})$ yielded green solid $1(0.014 \mathrm{~g}$, $11 \%)$ and green solid $2(0.056 \mathrm{~g}, 5 \%)$.

2. $\mathrm{MS}\left(\mathrm{ESI}^{+}\right)$: $m / z$ calculated for $\left[\mathrm{ReC}_{23} \mathrm{H}_{15} \mathrm{~N}_{4} \mathrm{~S}_{2} \mathrm{O}_{3}+\mathrm{H}\right]^{+} 647.0$, found 647.0, IR $\left(\mathrm{CH}_{2} \mathrm{Cl}_{2}\right)$ : vbar $=$ $1984,1887 \mathrm{~cm}^{-1}(\mathrm{CO})[14]$.

\subsection{Synthesis of $4 a$}

In a flame-dried Schlenk tube, bis $(\sigma)$ borate complex $\left[\mathrm{Mn}(\mathrm{CO})_{3}(\mu-\mathrm{H})_{2} \mathrm{BH}\left(\mathrm{RN}_{2} \mathrm{CSC}_{6} \mathrm{H}_{4}\right)\right],(\mathrm{R}=$ $\left.\mathrm{NCSC}_{6} \mathrm{H}_{4}\right) 3(0.100 \mathrm{~g}, 0.23 \mathrm{mmol})$ and $\mathrm{PPh}_{2} \mathrm{Me}(0.168 \mathrm{~g}, 0.69 \mathrm{mmol})$ were dissolved in $15 \mathrm{~mL}$ of toluene and allowed irradiation at 254-350 $\mathrm{nm}$ for $1 \mathrm{~h}$ at room temperature. The colour of the reaction 
mixture changed from yellow to orange. Then the solvent was evaporated in vacuum; residue was extracted into hexane/ $\mathrm{CH}_{2} \mathrm{Cl}_{2}(70: 30 \mathrm{v} / \mathrm{v})$ and passed through Celite. After the removal of solvent from filtrate, the residue was subjected to chromatographic workup using silica-gel TLC plates. Elution with hexane/ $\mathrm{CH}_{2} \mathrm{Cl}_{2}(70: 30 \mathrm{v} / \mathrm{v})$ yielded yellow solid $4 \mathrm{a}(0.045 \mathrm{~g}, 22 \%)$.

4a: $\mathrm{HRMS}\left(\mathrm{ESI}^{+}\right): \mathrm{m} / z$ calculated for $\left[\mathrm{C}_{42} \mathrm{H}_{34} \mathrm{MnN}_{3} \mathrm{O}_{2} \mathrm{~S}_{2} \mathrm{P}_{2}+\mathrm{H}\right]^{+} 794.1026$, found 794.1038 ; ${ }^{\circ} \mathrm{H} N M R$ $\left(500 \mathrm{MHz}, \mathrm{CDCl}_{3}, 22{ }^{\circ} \mathrm{C}\right): \delta=7.60-7.01(\mathrm{~m}, 28 \mathrm{H}, \mathrm{Ph}), 1.79 \mathrm{ppm}\left(\mathrm{s}, 6 \mathrm{H}, \mathrm{CH}_{3}\right) ;{ }^{13} \mathrm{C}\left\{{ }^{1} \mathrm{H}\right\}$ NMR $(125$ $\left.\mathrm{MHz}, \mathrm{CDCl}_{3}, 22^{\circ} \mathrm{C}\right): \delta=169.6(\mathrm{~s}, \mathrm{C}=\mathrm{N}), 153.1,146.5(\mathrm{~s}, \mathrm{CN}), 136.0,135.9(\mathrm{~s}, \mathrm{CS}), 132.1-115.7(\mathrm{~s}$, bbza), $155 \mathrm{ppm}(\mathrm{s}, \mathrm{Me}) ;{ }^{31} \mathrm{P}\left\{{ }^{1} \mathrm{H}\right\} \mathrm{NMR}\left(202 \mathrm{MHz}, \mathrm{CDCl}_{3}, 22{ }^{\circ} \mathrm{C}\right): \delta=50.7 \mathrm{ppm}$; IR $\left(\mathrm{CH}_{2} \mathrm{Cl}_{2}\right)$ : vbar $=1928,1851 \mathrm{~cm}^{-1}(\mathrm{CO})$.

\subsection{Synthesis of $\mathbf{4 b}$}

In a flame-dried Schlenk tube, complex $3(0.100 \mathrm{~g}, 0.23 \mathrm{mmol})$ and $\mathrm{PMe}_{2} \mathrm{Ph}(0.056 \mathrm{~g}, 0.40 \mathrm{mmol})$ were dissolved in $15 \mathrm{~mL}$ of toluene and allowed irradiation at $254-350 \mathrm{~nm}$ for $1 \mathrm{~h}$ at room temperature. The colour of the reaction mixture changed from yellow to orange. Then the solvent was evaporated in vacuum; residue was extracted into hexane $/ \mathrm{CH}_{2} \mathrm{Cl}_{2}(70: 30 \mathrm{v} / \mathrm{v})$ and passed through Celite. After the removal of solvent from filtrate, the residue was subjected to chromatographic workup using silica-gel TLC plates. Elution with hexane/ $\mathrm{CH}_{2} \mathrm{Cl}_{2}(70: 30 \mathrm{v} / \mathrm{v})$ yielded yellow solid $\mathbf{4 b}(0.040 \mathrm{~g}, 23 \%)$.

4b: HRMS (ESI ${ }^{+}$): $m / z$ calculated for $\left[\mathrm{C}_{32} \mathrm{H}_{30} \mathrm{MnN}_{3} \mathrm{O}_{2} \mathrm{~S}_{2} \mathrm{P}_{2}+\mathrm{H}\right]^{+} 670.0713$, found $670.0735 ;{ }^{1} \mathrm{H}$ NMR (500 MHz, $\left.\mathrm{CDCl}_{3}, 22{ }^{\circ} \mathrm{C}\right): \delta=7.61-6.98(\mathrm{~m}, 18 \mathrm{H}, \mathrm{Ph}), 1.57 \mathrm{ppm}\left(\mathrm{s}, 12 \mathrm{H}, \mathrm{CH}_{3}\right) ;{ }^{13} \mathrm{C}\left\{{ }^{1} \mathrm{H}\right\}$ NMR $(125$ $\left.\mathrm{MHz}, \mathrm{CDCl}_{3}, 22{ }^{\circ} \mathrm{C}\right): \delta=169.9(\mathrm{~s}, \mathrm{C}=\mathrm{N}), 153.3,146.7$ (s, CN), 138.0 (s, CS), 132.6-114.8 ppm (s, bbza), 15.4 ppm (s, Me); ${ }^{31} \mathrm{P}\left\{{ }^{1} \mathrm{H}\right\}$ NMR $\left(202 \mathrm{MHz}, \mathrm{CDCl}_{3}, 22{ }^{\circ} \mathrm{C}\right): \delta=35.6 \mathrm{ppm}$; IR $\left(\mathrm{CH}_{2} \mathrm{Cl}_{2}\right)$ : vbar $=1925,1848 \mathrm{~cm}^{-1}(\mathrm{CO})$.

\subsection{Synthesis of $\mathbf{5 a}, \mathbf{5 b}$ and $\mathbf{5 c}$ :}

In a flame-dried Schlenk tube, complex $3(0.100 \mathrm{~g}, 0.23 \mathrm{mmol})$ and ${ }^{\mathrm{t}} \mathrm{BuNC}(0.068 \mathrm{~g}, 0.92$ $\mathrm{mmol}$ ) were dissolved in $15 \mathrm{~mL}$ of toluene and allowed irradiation at $254-350 \mathrm{~nm}$ for $30 \mathrm{~min}$ at room temperature. The colour of the reaction mixture changed from yellow to orange. Then the solvent was evaporated in vacuum; residue was extracted into hexane $/ \mathrm{CH}_{2} \mathrm{Cl}_{2}(70: 30 \mathrm{v} / \mathrm{v})$ and passed through Celite. After the removal of solvent from filtrate, the residue was subjected to chromatographic 
workup using silica-gel TLC plates. Elution with hexane $/ \mathrm{CH}_{2} \mathrm{Cl}_{2}(70: 30 \mathrm{v} / \mathrm{v})$ yielded yellow solid $5 \mathbf{a}$ $(0.036 \mathrm{~g}, 24 \%)$ and orange solids $5 \mathbf{b}$ and $\mathbf{5 c}(0.023 \mathrm{~g}, 19 \%)$ [15].

5a. HRMS (ESI ${ }^{+}$): $m / z$ calculated for $\left[\mathrm{C}_{21} \mathrm{H}_{21} \mathrm{BMnN}_{4} \mathrm{O}_{2} \mathrm{~S}_{2}+\mathrm{H}\right]^{+} 491.0582$, found $491.0582 ;{ }^{11} \mathrm{~B}\left\{{ }^{1} \mathrm{H}\right\}$ $\operatorname{NMR}\left(160 \mathrm{MHz}, \mathrm{CDCl}_{3}, 22{ }^{\circ} \mathrm{C}\right): \delta=19.8 \mathrm{ppm} ;{ }^{1} \mathrm{H}$ NMR $\left(500 \mathrm{MHz}, \mathrm{CDCl}_{3}, 22{ }^{\circ} \mathrm{C}\right): \delta=8.43-7.30$ (m, 8H, Ph), $4.75\left(\mathrm{br}, 1 \mathrm{H}, \mathrm{BH}_{\mathrm{t}}\right), 1.38\left(\mathrm{~s}, 9 \mathrm{H}, \mathrm{CMe}_{3}\right),-8.79$ and $-12.37 \mathrm{ppm}(\mathrm{br}, 2 \mathrm{H}, \mathrm{Mn}-\mathrm{H}-\mathrm{B}) ;{ }^{13} \mathrm{C}\left\{{ }^{1} \mathrm{H}\right\}$ NMR (125 MHz, $\left.\mathrm{CDCl}_{3}, 22{ }^{\circ} \mathrm{C}\right): \delta=169.9(\mathrm{~s}, \mathrm{C}=\mathrm{N}), 151.0,146.8(\mathrm{~s}, \mathrm{CN}), 139.5$ (s, CS), 127.0113.6 (s, bbza), $41.3\left(\mathrm{~s}, \mathrm{CMe}_{3}\right), 30.8 \mathrm{ppm}\left(\mathrm{s}, \mathrm{CMe}_{3}\right)$; IR $\left(\mathrm{CH}_{2} \mathrm{Cl}_{2}\right)$ : vbar = $2306\left(\mathrm{BH}_{\mathrm{t}}\right), 2138\left(\mathrm{BH}_{\mathrm{b}}\right)$, $1969,1902 \mathrm{~cm}^{-1}(\mathrm{CO})$.

5b and 5c. HRMS (ESI $\left.{ }^{+}\right): m / z$ calculated for $\left[\mathrm{C}_{25} \mathrm{H}_{30} \mathrm{BMnN}_{5} \mathrm{OS}_{2}+\mathrm{H}\right]^{+}$546.1369, found 546.1365; ${ }^{11} \mathrm{~B}\left\{{ }^{1} \mathrm{H}\right\} \mathrm{NMR}\left(160 \mathrm{MHz}, \mathrm{CDCl}_{3}, 22{ }^{\circ} \mathrm{C}\right): \delta=19.4$ and $16.4 \mathrm{ppm} ;{ }^{1} \mathrm{H}$ NMR $\left(500 \mathrm{MHz}, \mathrm{CDCl}_{3}, 22{ }^{\circ} \mathrm{C}\right)$ : $\delta=7.87-7.48(\mathrm{~m}, 8 \mathrm{H}, \mathrm{Ph}), 4.52\left(\mathrm{br}, 2 \mathrm{H}, \mathrm{BH}_{\mathrm{t}}\right), 1.38$ and $1.37\left(\mathrm{~s}, 18 \mathrm{H}, 2 \mathrm{CMe}_{3}\right),-7.62$ and $-11.95 \mathrm{ppm}$ (br, 4H, Mn-H-B); ${ }^{13} \mathrm{C}\left\{{ }^{1} \mathrm{H}\right\}$ NMR (125 MHz, $\left.\mathrm{CDCl}_{3}, 22{ }^{\circ} \mathrm{C}\right): \delta=166.2(\mathrm{~s}, \mathrm{C}=\mathrm{N}), 149.1,(\mathrm{~s}, \mathrm{CN})$, 132.8 (s, CS), 126.1-121.0 (s, bbza), $56.9\left(\mathrm{~s}, \mathrm{CMe}_{3}\right), 31.7,31.3 \mathrm{ppm}\left(\mathrm{s}, \mathrm{CMe}_{3}\right) ; \mathrm{IR}\left(\mathrm{CH}_{2} \mathrm{Cl}_{2}\right)$ : vbar $=$ $2345\left(\mathrm{BH}_{\mathrm{t}}\right), 2114,2039\left(\mathrm{BH}_{\mathrm{b}}\right), 1882 \mathrm{~cm}^{-1}(\mathrm{CO})$.

\subsection{Synthesis of 7 :}

In a flame-dried Schlenk tube, borate complex $\left[\mathrm{Mn}(\mathrm{CO})_{3}\left\{\kappa^{3}-\mathrm{S}, \mathrm{S}^{\prime}, \mathrm{H}-\mathrm{H}_{2} \mathrm{~B}(\mathrm{mbz})_{2}\right\}\right], 6(0.100 \mathrm{~g}$, $0.206 \mathrm{mmol})$ and $\mathrm{PPh}_{3}(0.059 \mathrm{~g}, 0.23 \mathrm{mmol})$ were dissolved in $15 \mathrm{~mL}$ of toluene and allowed irradiation for $2 \mathrm{~h}$ at room temperature. Then the solvent was evaporated in vacuum; residue was extracted into hexane/ $\mathrm{CH}_{2} \mathrm{Cl}_{2}(70: 30 \mathrm{v} / \mathrm{v})$ and passed through Celite. After the removal of solvent from filtrate, the residue was subjected to chromatographic workup using silica-gel TLC plates. Elution with hexane $/ \mathrm{CH}_{2} \mathrm{Cl}_{2}(25: 75 \mathrm{v} / \mathrm{v})$ yielded red solid 7 (0.042 $\left.\mathrm{g}, 28 \%\right)$.

7. $\mathrm{HRMS}\left(\mathrm{ESI}^{+}\right): \mathrm{m} / z$ calculated for $\left[\mathrm{C}_{34} \mathrm{H}_{25} \mathrm{BMnN}_{2} \mathrm{O}_{2} \mathrm{PS}_{4}+\mathrm{Na}\right]^{+} 740.9908$, found $740.9892 ;{ }^{11} \mathrm{~B}\left\{{ }^{1} \mathrm{H}\right\}$ $\operatorname{NMR}\left(160 \mathrm{MHz}, \mathrm{CDCl}_{3}, 22{ }^{\circ} \mathrm{C}\right): \delta=19.5 \mathrm{ppm} ;{ }^{1} \mathrm{H} \mathrm{NMR}\left(500 \mathrm{MHz}, \mathrm{CDCl}_{3}, 22{ }^{\circ} \mathrm{C}\right): \delta=7.82(\mathrm{~d}, J=$ $7.6 \mathrm{~Hz}, 1 \mathrm{H}), 7.72(\mathrm{q}, J=7.4 \mathrm{~Hz}, 2 \mathrm{H}), 7.64(\mathrm{~d}, J=8.2 \mathrm{~Hz}, 2 \mathrm{H}), 7.59$ (d, $J=7.8 \mathrm{~Hz}, 2 \mathrm{H}), 7.51(\mathrm{t}, J=$ $7.6 \mathrm{~Hz}, 5 \mathrm{H}), 7.40(\mathrm{~m}, 5 \mathrm{H}), 7.33(\mathrm{~m}, 6 \mathrm{H}), 4.27$ (br, $\left.1 \mathrm{H}, \mathrm{BH}_{\mathrm{t}}\right),-9.67 \mathrm{ppm}(\mathrm{br}, 1 \mathrm{H}, \mathrm{Mn}-\mathrm{H}-\mathrm{B}) ;{ }^{31} \mathrm{P}\left\{{ }^{1} \mathrm{H}\right\}$ NMR (202 MHz, $\left.\mathrm{CDCl}_{3}, 22^{\circ} \mathrm{C}\right): \delta=8.4 \mathrm{ppm}$; IR (KBr, v, cm-1): $2468\left(\mathrm{~B}-\mathrm{H}_{\mathrm{t}}\right), 1949$ (CO).

\section{X-ray Structure Determination:}


Crystallographic information for compounds 2, 4a, 4b and 7 are described below. Crystal diffraction data for $\mathbf{2}$ and 4a were collected and integrated using a D8 VENTURE Bruker AXS diffractometer with multilayers monochromated $\mathrm{Mo}_{\alpha}(\lambda=0.71073 \AA)$ radiation either at $150 \mathrm{~K}$ or room temperature. Crystal diffraction data of 7 was collected and integrated using a Bruker P4

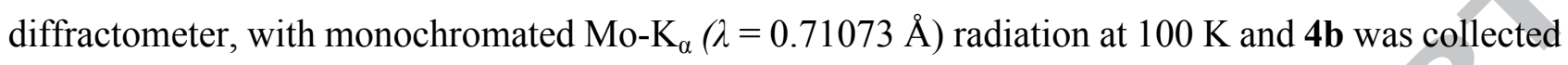
and integrated using a Bruker AXS Kappa APEX2 CCD diffractometer equipped with graphite monochromated Mo-K $\mathrm{K}_{\alpha}(\lambda=0.71073 \AA)$ radiation at room temperature. The structures were solved by direct methods using SIR92 [16] or via a dual-space algorithm using the SHELXT program [17] and refined using SHELXL-2014 [18].

Crystal data for 2: CCDC: $1886985, \mathrm{C}_{23} \mathrm{H}_{15} \mathrm{~N}_{4} \mathrm{O}_{3} \mathrm{ReS}_{2}, M_{\mathrm{r}}=645.71$, triclinic, space group $P-1, a=$ 9.2634(8) $\AA, b=11.4125(11) \AA, c=11.7015(11) \AA, \alpha=72.699(3)^{\circ}, \beta=82.107(3)^{\circ}, \gamma=81.844(3)^{\circ}$, $V=1163.21(19) \AA^{3}, Z=2, \rho_{\text {calcd }}=1.844 \mathrm{~g} \mathrm{~cm}^{-3}, \mu=5.436 \mathrm{~mm}^{-1}, F(000)=624, R_{1}=0.0199, w R_{2}=$ $0.0622,5320$ independent reflections $\left[2 \theta \leq 54.97^{\circ}\right]$ and 299 parameters.

Crystal data for 4a: CCDC: $1886987, \mathrm{C}_{42} \mathrm{H}_{34} \mathrm{MnN}_{3} \mathrm{O}_{2} \mathrm{P}_{2} \mathrm{~S}_{2}, M_{\mathrm{r}}=793.72$, monoclinic, space group $P 2{ }_{1} / c, a=20.7461(5) \AA, b=11.1107(2) \AA, c=17.0743(4) \AA, \alpha=90^{\circ}, \beta=101.0060(10)^{\circ}, \gamma=90^{\circ}, V$ $=3863.30(15) \AA^{3}, Z=4, \rho_{\text {calcd }}=1.365 \mathrm{~g} \mathrm{~cm}^{-3}, \mu=0.573 \mathrm{~mm}^{-1}, F(000)=1640, R_{1}=0.0339, w R_{2}=$ $0.0923,6811$ independent reflections $\left[2 \theta \leq 55.72^{\circ}\right]$ and 471 parameters.

Crystal data for 4b: CCDC: $1886986, \mathrm{C}_{32} \mathrm{H}_{30} \mathrm{MnN}_{3} \mathrm{O}_{2} \mathrm{P}_{2} \mathrm{~S}_{2}, M_{\mathrm{r}}=669.59$, monoclinic, space group $P 2{ }_{1} / c, a=17.4469(14) \AA, b=13.9261(12) \AA, c=12.8197(13) \AA, \alpha=90^{\circ}, \beta=94.068(3)^{\circ}, \gamma=90^{\circ}, V$ $=3106.9(5) \AA^{3}, Z=4, \rho_{\text {calcd }}=1.431 \mathrm{~g} \mathrm{~cm}^{-3}, \mu=0.697 \mathrm{~mm}^{-1}, F(000)=1384, R_{1}=0.0273, w R_{2}=$ $0.0710,7120$ independent reflections $\left[2 \theta \leq 54.964^{\circ}\right]$ and 383 parameters.

Crystal data for 7: $\mathrm{CCDC} 1835499, \mathrm{C}_{34} \mathrm{H}_{25} \mathrm{BMnS}_{4} \mathrm{~N}_{2} \mathrm{PO}_{2}, M_{\mathrm{r}}=803.44$, triclinic, $P-1, a=9.6544(8)$ $\AA, b=12.5732(12) \AA, c=16.3798(14) \AA, \alpha=90.565(3)^{\circ}, \beta=107.043(3)^{\circ}, \gamma=111.498(3)^{\circ}, V=$ $1753.3(3) \AA^{3}, Z=2, \rho_{\text {calcd }}=1.522 \mathrm{mg} / \mathrm{m}^{3}, \mu=0.849 \mathrm{~mm}^{-1}, F(000)=820, R_{1}=0.0563, w R_{2}=0.1058$, 8039 independent reflections $\left[2 \theta \leq 54.968^{\circ}\right], 439$ parameters.

\section{Results and Discussion}

\subsection{Reactivity of $\operatorname{Re}_{2}(\mathrm{CO})_{10}$ with $\mathrm{Na}\left[\left(\mathrm{H}_{3} \mathrm{~B}\right) \mathrm{bbza}\right]$ ligand:}


The chemistry of metal complexes containing $f a c-\mathrm{M}(\mathrm{CO})_{3}\left(\mathrm{M}=\mathrm{Re}\right.$ or $\left.{ }^{99 \mathrm{~m}} \mathrm{Tc}\right)$ has extensively been studied as radioactive probe for targeting brain 5- $\mathrm{HT}_{1 \mathrm{~A}}$ serotonergic receptors by Santos et al. [4e]. In order to synthesize similar type of borate complexes of group-7 transition metals, earlier we have investigated the reaction of trihydrobis(benzothiazol-2-yl)amideborate, $\mathrm{Na}\left[\left(\mathrm{H}_{3} \mathrm{~B}\right) \mathrm{bbza}\right]$ with $\mathrm{M}_{2}(\mathrm{CO})_{10}(\mathrm{M}=\mathrm{Mn}$ or $\mathrm{Re})[11]$. In case of manganese, the reaction led to the formation of bis $(\sigma)$ borate complex $\left[\mathrm{Mn}(\mathrm{CO})_{3}(\mu-\mathrm{H})_{2} \mathrm{BHNCSC}_{6} \mathrm{H}_{4}(\mathrm{NR})\right], 3\left(\mathrm{R}=\mathrm{NCSC}_{6} \mathrm{H}_{4}\right)$, whereas, the reaction with $\mathrm{Re}_{2}(\mathrm{CO})_{10}$ yielded octahedral complex $\left[\mathrm{Re}(\mathrm{CO})_{2}\left(\mathrm{~N}_{3} \mathrm{C}_{2} \mathrm{~S}_{2} \mathrm{C}_{12} \mathrm{H}_{8}\right)_{2}\right], 1$ [11]. As we failed to isolate the $\operatorname{bis}(\sigma)$ borate complex of rhenium, we revisited this reaction under different conditions. As a result, we have isolated another compound $\mathbf{2}$ in very less yield along with known compound $\mathbf{1}$ (Scheme 1).

Compound 2 was isolated by thin layer chromatographic (TLC) separation. This compound was characterized by limited spectroscopic data in combination with mass spectrometric and single crystal X-ray diffraction data. The ${ }^{1} \mathrm{H}$ NMR spectrum shows a peak at $\delta=4.04 \mathrm{ppm}$ for the methyl protons. Infrared spectrosocpic data confirms the presence of both bbza ligand and carbonyl ligands.

The mass spectrum of 2 showed a molecular ion peak at $m / z 647.0[\mathrm{M}+\mathrm{H}]^{+}$. Consistent with the spectroscopic data, the authenticity of $\mathbf{2}$ was confirmed by X-ray crystallographic analysis. The solidstate X-ray structure of 2, shown in Figure 2, shows that the central metal rhenium is in distorted
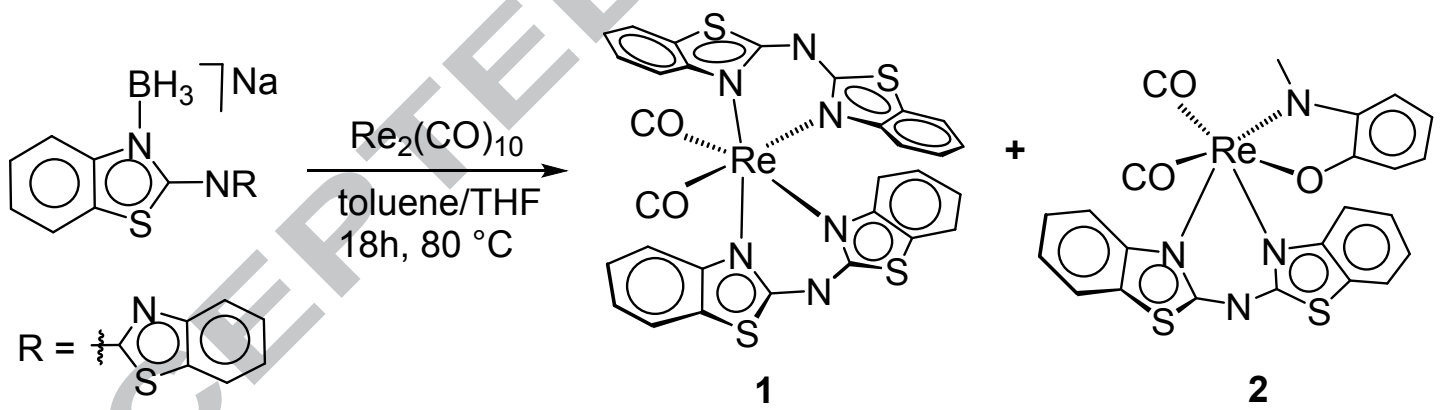

Scheme 1. Synthesis of compounds 1 and 2.

octahedral environment and resides $0.013 \AA$ far from the mean plane of $\{\mathrm{N} 1-\mathrm{O} 3-\mathrm{C} 22-\mathrm{C} 23\}$ and comparable to the $c i s-\left[\mathrm{ReO}_{2}(\mathrm{Hdab})(\mathrm{py})_{2}\right](\mathbf{1})\left(\mathrm{H}_{2} \mathrm{dab}=1,2\right.$-diaminobenzene) [19]. Complex 2 is an example of neutral hexacoordinate rhenium complex with a cis arrangement of the two carbonyl ligands. We believe that the sources of oxygen and methyl group in $\mathbf{2}$ might be the carbonyl ligand.

\subsection{Reactivity of Mn-bis( $\sigma)$ borate, 3 with phosphine ligands}


Having failed to isolate the bis $(\sigma)$ borate of rhenium, we have moved our attention to synthesise manganese bis $(\sigma)$ borate complexes. In our earlier report, we have demonstrated the reaction of $\left[\mathrm{Mn}(\mathrm{CO})_{3}(\mu-\mathrm{H})_{2} \mathrm{BHNCSC}_{6} \mathrm{H}_{4}(\mathrm{NR})\right], 3$ with $\mathrm{PL}_{2} \mathrm{~L}^{\prime}\left(\mathrm{L}=\mathrm{Ph}\right.$ or $\left.\mathrm{L}^{\prime}=\mathrm{Me}\right)$ and that yielded the isomeric bis $(\sigma)$ borate complexes $\left[\mathrm{Mn}(\mu-\mathrm{H})_{2}\left(\mathrm{BHNCSC}_{6} \mathrm{H}_{4}\right)\{\mathrm{NR}\}(\mathrm{CO})_{2} \mathrm{PL}_{2} \mathrm{~L}^{\prime}\right]$ and $\left[\mathrm{Mn}(\mu-\mathrm{H})_{2} \mathrm{BHN}(\mathrm{NCS}-\right.$ $\left.\left.\mathrm{C}_{6} \mathrm{H}_{4}\right) \mathrm{R}(\mathrm{CO})_{2} \mathrm{PL}_{2} \mathrm{~L}^{\prime}\right]\left(\mathrm{L}=\mathrm{Ph}, \mathrm{L}^{\prime}=\mathrm{Ph}\right.$ or $\left.\mathrm{Me} ; \mathrm{R}=\mathrm{NCSC}_{6} \mathrm{H}_{4}\right)$. In order to check the lability of the metal-carbon bond in $\mathbf{3}$, we carried out the reaction with phosphine ligands, which are strong $\sigma$-donors and comparatively poor $\pi$-acceptors. Therefore, room temperature photolysis of $\mathbf{3}$ with excess amount of phosphine ligands was investigated and that yielded manganese-phosphine complexes $\left[\mathrm{Mn}(\mathrm{CO})_{2}\left(\mathrm{PL}_{2} \mathrm{~L}^{\prime}\right)_{2}\left\{\mathrm{~N}\left(\mathrm{C}_{7} \mathrm{H}_{4} \mathrm{NS}\right)_{2}\right\}\right],\left(\mathbf{4 a}: \mathrm{L}=\mathrm{Ph}, \mathrm{L}^{\prime}=\mathrm{Me}, 4 \mathbf{b}: \mathrm{L}=\mathrm{Me}, \mathrm{L}^{\prime}=\mathrm{Ph}\right)(\mathrm{Scheme} 2)$. Both the

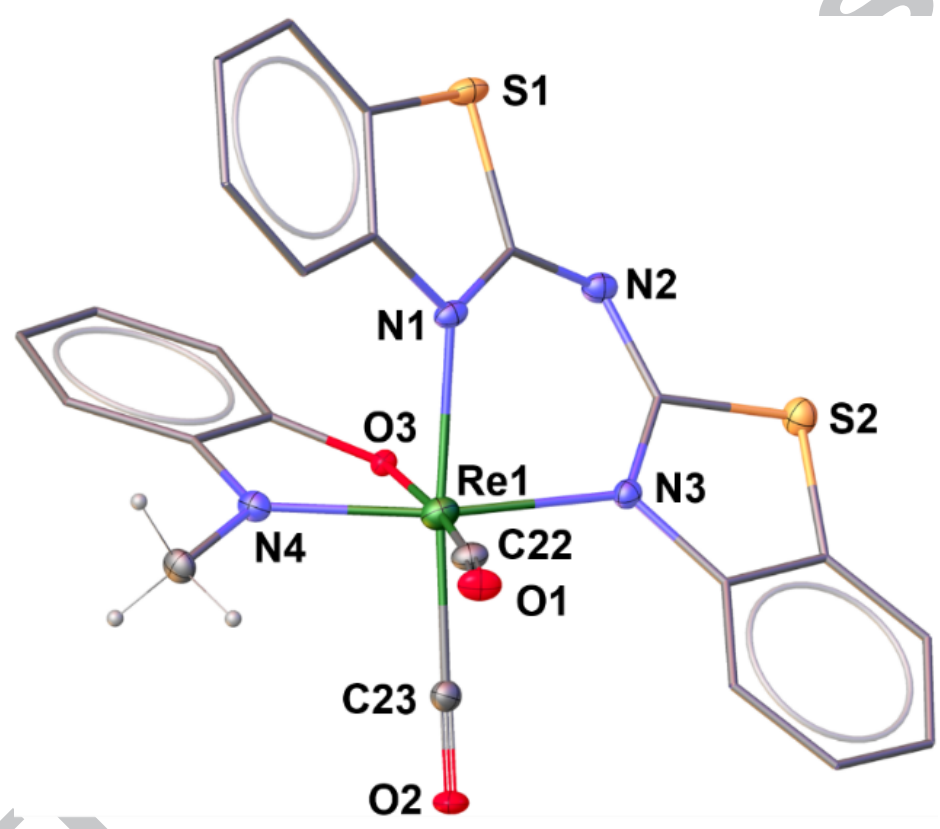

Figure 2. Molecular structure of compound 1 in the solid state. All hydrogen atoms (except on methyl units) have been removed for clarity. Selected bond lengths $(\AA)$ and bond angles $\left(^{\circ}\right)$ : $\operatorname{Re} 1-\mathrm{C} 23$ 1.960(3), Re1-O3 2.106(2), Re1-N3 2.114(3), Re1-N1 2.129(3); N4-Re1-O3 77.84(10).

compounds were isolated in good yields and were separated using thin layer chromatographic technique and characterized by multi-nuclear NMR and IR spectroscopy, mass spectrometry and Xray diffraction studies. Note that, no ${ }^{11} \mathrm{~B}$ chemical shift was observed for both $4 \mathbf{a}$ and $4 \mathbf{b}$ in the ${ }^{11} \mathrm{~B}\left\{{ }^{1} \mathrm{H}\right\}$ NMR spectra and that confirmed the absence of boron in these compounds. The mass spectrometric analysis of $\mathbf{4 a}$ and $\mathbf{4 b}$ shows molecular ion peaks at $m / z 794.1038$ and 670.0735 respectively. On the other hand, the ${ }^{1} \mathrm{H}$ NMR spectra of $\mathbf{4 a}$ and $\mathbf{4 b}$ showed chemical shifts for protons present in bbza 
ligand, phenyl and the methyl groups. The ${ }^{31} \mathrm{P}\left\{{ }^{1} \mathrm{H}\right\}$ NMR spectra showed the chemical shifts at $\delta=$ 50.7 and $35.6 \mathrm{ppm}$ for compounds $\mathbf{4 a}$ and $\mathbf{4 b}$, respectively. In addition to this, the IR spectra confirmed the presence of $\mathrm{CO}$ ligands in both the compounds. The identity of compounds $4 \mathbf{a}$ and $\mathbf{4 b}$ were finaly confirmed by X-ray diffraction analysis.

X-ray quality crystals of both $\mathbf{4 a}$ and $\mathbf{4 b}$ were obtained from the slow evaporation of hexane and $\mathrm{CH}_{2} \mathrm{Cl}_{2}$ mixture at $-5{ }^{\circ} \mathrm{C}$. The solid state $\mathrm{X}$-ray structures of them shown in Figure 3, clearly show that one of the $\mathrm{CO}$ ligands is replaced by a phosphine and another unit of a phosphine ligand coordinated to the metal centre by replacing the borate unit. The average Mn-P bond length (2.2997 $\AA)$ in $\mathbf{4 a}$ and $\mathbf{4 b}$ is comparable to that in $\left[\mathrm{Mn}(\mathrm{CO})_{4}\left(\mathrm{PPhMe}_{2}\right)\left(\mathrm{BH}_{2} \cdot \mathrm{PMe}_{3}\right)\right](2.302(1) \AA)$ [20] and longer than that in the manganese bis $(\sigma)$ borate complexes $\left[\mathrm{Mn}(\mu-\mathrm{H})_{2}\left(\mathrm{BHNCSC}_{6} \mathrm{H}_{4}\right)\{\mathrm{NR}\}(\mathrm{CO})_{2^{-}}\right.$ $\left.\mathrm{PL}_{2} \mathrm{~L}^{\prime}\right]\left(\mathrm{L}=\mathrm{Ph}, \mathrm{L}^{\prime}=\mathrm{Ph}\right.$ or Me; $\left.\mathrm{R}=\mathrm{NCSC}_{6} \mathrm{H}_{4}\right)(2.257 \AA)$ [11]. However, the distances between $\mathrm{Mn}$ and $\mathrm{C}$ in 4a (Mn1-C7 2.539(2) $\AA$ ) and 4b (Mn1-C27 2.5289(14) $\AA$ ) are in the higher range of manganese-carbon single bond distance [21]. These apparent bonds are a result of the very close proximity of the two centers ( $\mathrm{Mn}$ and $\mathrm{C}$ ), due to the $\mathrm{NN}$ chelation. Phosphine $\left(\mathrm{PR}_{3}\right)$ show an important role in coordination and organometallic chemistry because of their wide range of coordination [2228]. Many of metal phosphine complexes used as catalysts [29, 30]. In adition, transition-metal-
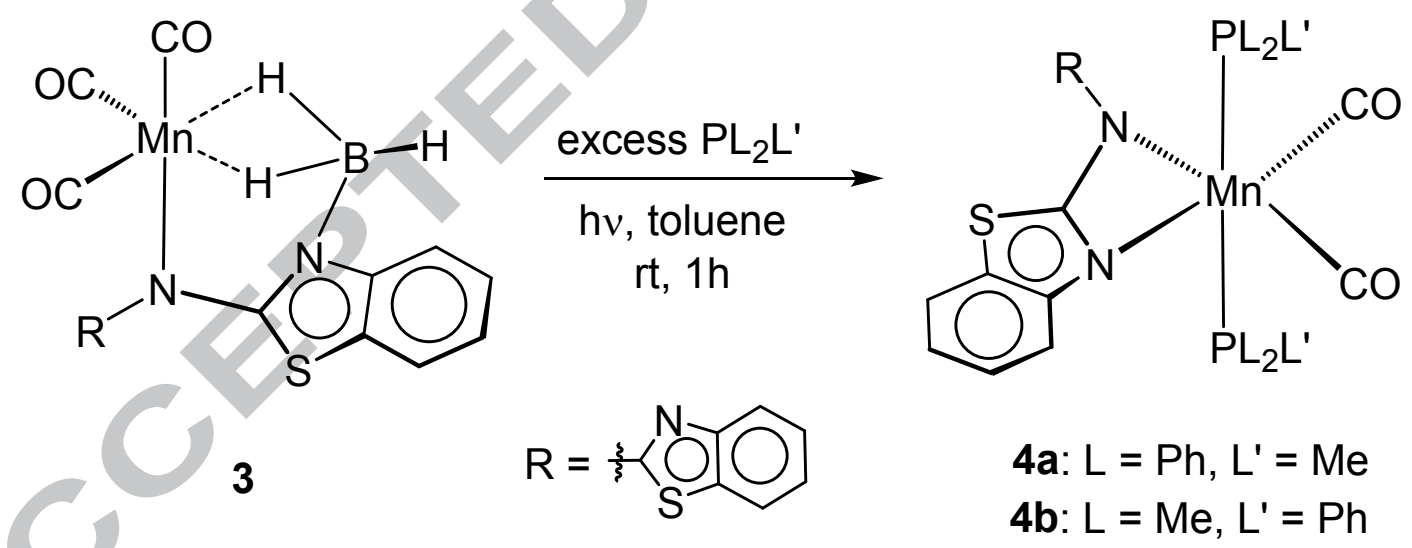

Scheme 2. Reactivity of compound 3 with phosphines.

phosphine complexes can activate small molecules, such as $\mathrm{H}_{2}, \mathrm{~N}_{2}, \mathrm{O}_{2}, \mathrm{H}_{2} \mathrm{O}$ and $\mathrm{CO}_{2}$ etc. So, complexes $\mathbf{4 a}$ and $\mathbf{4 b}$ certainly a good entry in the list of transition-metal-phosphine complexes.

Computational studies of $4 \boldsymbol{a}$ and $\mathbf{4 b}$ : In order to know the nature of metal to ligand coordination, we have performed the DFT calculations at BP86/Def2-SVP level, starting from the coordinates obtained 
from the X-ray structure [31]. A quick look into the molecular orbitals of 4a suggests that the electron density at HOMO is located at manganese, carbonyl ligands and mostly on benzothiazole moiety. The LUMO is located at manganese, one phenyl ring of $\mathrm{PPh}_{2} \mathrm{Me}$ and benzothiazole moiety (Figure S25). The HOMO-LUMO energy gap is about $2.48 \mathrm{eV}$, which is lesser than its parent molecule $3(2.95 \mathrm{eV})$ that infers the stability of $\mathbf{4 a}$. In case of $\mathbf{4 b}$ the electron density in HOMO is mainly located at manganese and carbonyl ligands whereas LUMO is located mainly at benzothiazole moiety (Figure S26). The HOMO-LUMO energy gap (2.52 eV) is almost similar to that of compound 4a. This might confer comparable thermodynamic stability of $\mathbf{4 a}$ and $\mathbf{4 b}$.

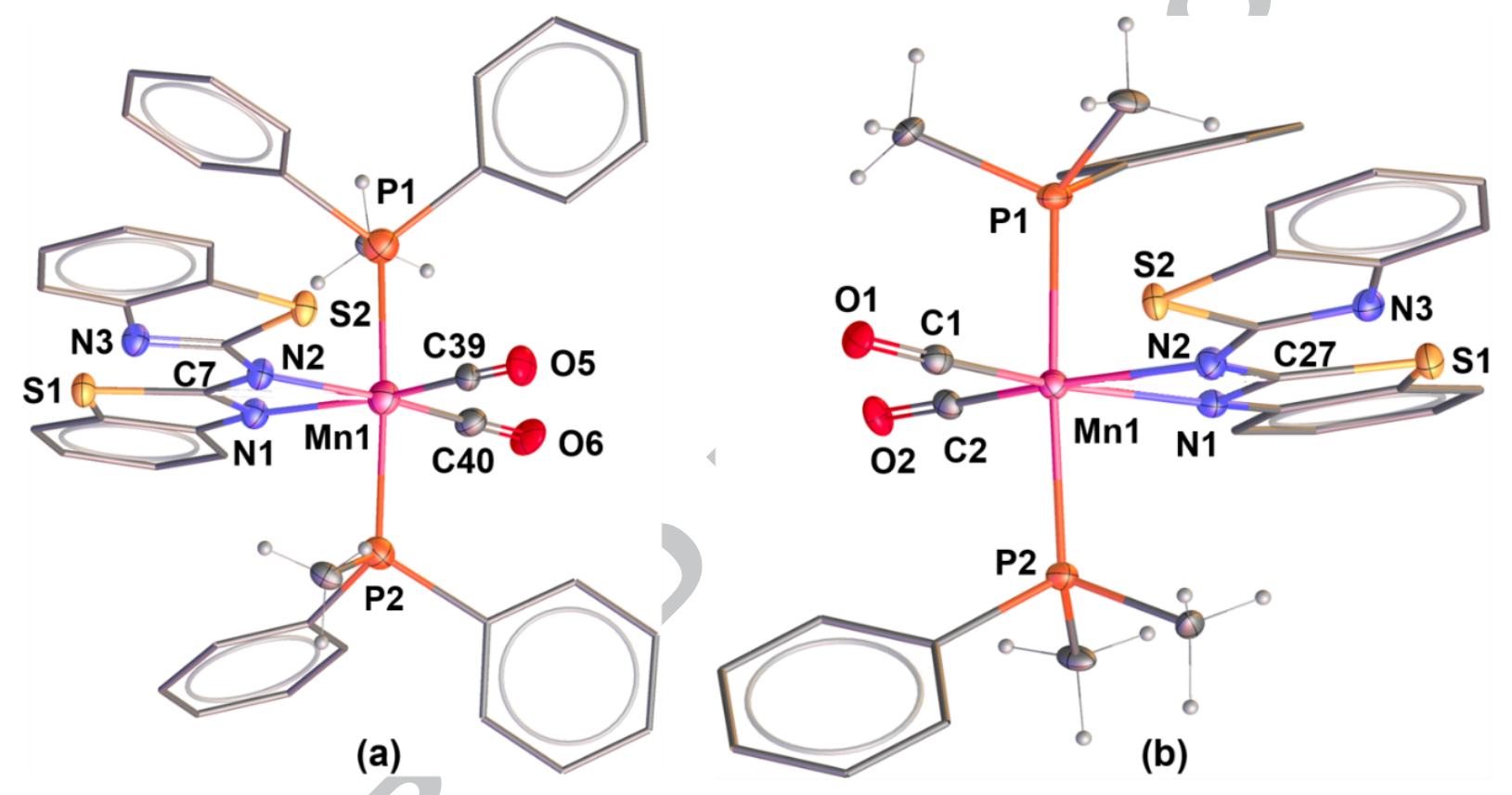

Figure 3. Molecular structure of compounds $\mathbf{4 a}$ and $\mathbf{4 b}$ in the solid state. All hydrogen atoms (except on methyl units) have been removed for clarity. Selected bond lengths $(\AA)$ and bond angles $\left(^{\circ}\right)$ of $4 \mathbf{a}$ (a): Mn1-P1 2.3121(7), Mn1-P2 2.2899(7), Mn1-N2 2.1013(18), C40-Mn1 1.764(3), C39-Mn1 1.771(2), N1-C7-Mn1 56.58(11), N2-C7-Mn1 55.76(11), S1-C7-Mn1 172.52(13), C40-Mn1-C39 93.00(11); 4b (b) Mn1-P1 2.2904(4), Mn1-P2 2.3066(4), Mn1-N1 2.0782(12), Mn1-N2 2.1186(13), C2-Mn1-C1 90.12(7), P1-Mn1-P2 175.713(16).

\subsection{Reactivity of Mn-bis( $\sigma)$ borate, 3 with ${ }^{t} B u N C$}

Isocyanide ligands are strong $\sigma$-donors and comparatively poor $\pi$-acceptors [27]. Therefore, to study the labile nature of manganese carbonyl bond, we treated 3 with excess amount of ${ }^{t} \mathrm{BuNC}$. As shown in Scheme 3, treatment of $\mathbf{3}$ with ${ }^{t} \mathrm{BuNC}$ yielded the bis $(\sigma)$ borate complexes of manganese 
$\left[\mathrm{Mn}(\mu-\mathrm{H})_{2}\left(\mathrm{BHNCSC}_{6} \mathrm{H}_{4}\right)(\mathrm{NR})(\mathrm{CO})_{\mathrm{x}} \mathrm{L}_{\mathrm{y}}\right], \mathbf{5 a}-\mathbf{b}\left(\mathbf{5 a}: \mathrm{x}=2, \mathrm{y}=1 ; \mathbf{5 b}: \mathrm{x}=1 ; \mathrm{y}=2 ; \mathrm{L}={ }^{t} \mathrm{BuNC} ; \mathrm{R}=\right.$ $\left.\mathrm{NCSC}_{6} \mathrm{H}_{4}\right)$ and $\left[\mathrm{Mn}(\mu-\mathrm{H})_{2} \mathrm{BH}\left\{\mathrm{N}\left(\mathrm{NCSC}_{6} \mathrm{H}_{4}\right)_{2}\right\}(\mathrm{CO})\left({ }^{(t} \mathrm{BuNC}\right)_{2}\right]$, 5c. The ${ }^{11} \mathrm{~B}\left\{{ }^{1} \mathrm{H}\right\}$ chemical shift of compound $5 \mathbf{a}$ appeared at the downfield region $(\delta=19.8 \mathrm{ppm})$ as compared to the starting material, $3(\delta=17.3 \mathrm{ppm})$. Compound 5a displayed ${ }^{1} \mathrm{H}$ NMR resonances at $\delta=4.75 \mathrm{ppm}$ and $\delta=1.38 \mathrm{ppm}$ due to terminal $\mathrm{BH}$ and ${ }^{t} \mathrm{Bu}$ protons, respectively. In addition, peaks at $\delta=-8.79$ and $-12.37 \mathrm{ppm}$ in 1:1 ratio, were assigned for the bridging Mn-H-B protons. High resolution mass spectrometry experiment was carried out for $\mathbf{5 a}$ and the result provided molecular mass consistent with the formula $\mathrm{C}_{21} \mathrm{H}_{21} \mathrm{BMnN}_{4} \mathrm{O}_{2} \mathrm{~S}_{2}$. Based on the spectroscopic assignment of the $\mathbf{5 a}$, the molecular formula of $\mathbf{5 a}$ is $\left[\mathrm{Mn}(\mu-\mathrm{H})_{2}\left(\mathrm{BHNCSC}_{6} \mathrm{H}_{4}\right)(\mathrm{NR})(\mathrm{CO})_{2}\left({ }^{(} \mathrm{BuNC}\right)\right]\left(\mathrm{R}=\mathrm{NCSC}_{6} \mathrm{H}_{4}\right)$ in which a ${ }^{t} \mathrm{BuNC}$ group replaced one of the carbonyl ligands of compound $\mathbf{3}$.

Note that compounds $\mathbf{5 b}$ and $\mathbf{5} \mathbf{c}$ were inseparable orange solids and our repeated attempts to isolate $\mathbf{5 b}$ and $\mathbf{5 c}$ in pure form met with no success. Hence, they have been characterized using combined spectroscopic data. The ${ }^{11} \mathrm{~B}\left\{{ }^{1} \mathrm{H}\right\}$ chemical shifts of compounds $\mathbf{5 b}$ and $\mathbf{5} \mathbf{c}$ are close to each other $(\delta=19.4$ and $16.4 \mathrm{ppm})$. The ${ }^{1} \mathrm{H}$ NMR chemical shifts confirm the presence of two ${ }^{t} \mathrm{Bu}$ groups, two Mn-H-B protons and one terminal B-H proton for both the compounds. High resolution mass spectrometry experiment carried out on $\mathbf{5 b}$ and $\mathbf{5 c}$ provided molecular mass consistent with the formula $\mathrm{C}_{25} \mathrm{H}_{30} \mathrm{BMnN}_{5} \mathrm{OS}_{2}$. All our efforts to grow the crystals for $\mathbf{5 a - c}$ were futile and the molecular formulae were predicted based on the spectroscopic data in combination with mass spectrometric data.

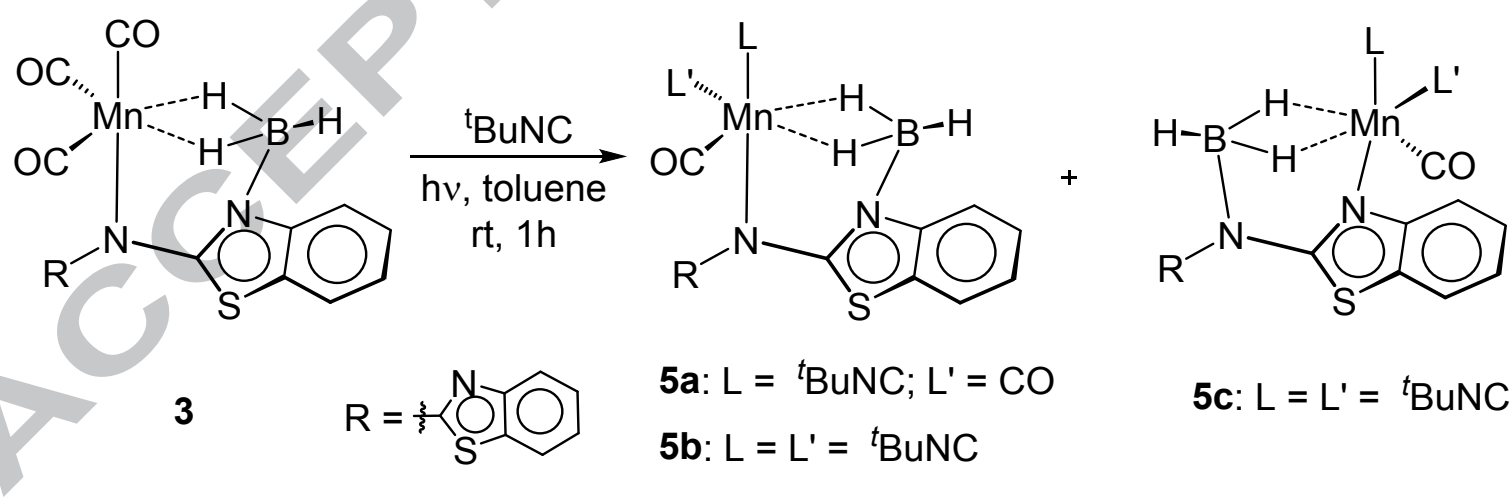

Scheme 3. Reactivity of compound $\mathbf{3}$ with ${ }^{t} \mathrm{BuNC}$.

Therefore, the molecular formula for $\mathbf{5 b}$ and $\mathbf{5} \mathbf{c}$ assigned as $\left[\mathrm{Mn}(\mu-\mathrm{H})_{2}\left(\mathrm{BHNCSC}_{6} \mathrm{H}_{4}\right)(\mathrm{NR})(\mathrm{CO})-\right.$ $\left.\left({ }^{t} \mathrm{BuNC}\right)_{2}\right], \mathbf{5 b}\left(\mathrm{R}=\mathrm{NCSC}_{6} \mathrm{H}_{4}\right)$ and $\left[\mathrm{Mn}(\mu-\mathrm{H})_{2} \mathrm{BH}\left\{\mathrm{N}\left(\mathrm{NCSC}_{6} \mathrm{H}_{4}\right)_{2}\right\}-(\mathrm{CO})\left({ }^{t} \mathrm{BuNC}\right)_{2}\right], \mathbf{5 c}$. 
Compounds $\mathbf{5 b}$ and $\mathbf{5 c}$ can be called as isomers by considering the molecular formula, geometry and ${ }^{11} \mathrm{~B}$ chemical shift values. Similar kind of behavior was observed when 8 -aminoquinoline and 2aminopyridine ligands were treated with group-8 metal precursors [30]. Thus, the formation of $\mathbf{5 b}$ and 5c might have happened due to the reverse translocation of the bbza ligand between Mn and boron atom. Although there are some cases that are known, formation of such type of complexes are unusual. For example, $\left[\mathrm{Os}\left\{\mathrm{B}(\mathrm{OEt})\left(\mathrm{NC}_{5} \mathrm{H}_{4} \mathrm{NH}\right)\right\} \mathrm{Cl}(\mathrm{CO})\left(\mathrm{PPh}_{3}\right)_{2}\right]$ vs $\left[\mathrm{Os}\left\{\mathrm{BCl}\left(\mathrm{NHC}_{5} \mathrm{H}_{4} \mathrm{~N}\right)\right\} \mathrm{Cl}(\mathrm{CO})-\left(\mathrm{PPh}_{3}\right)_{2}\right]$ and [Os $\left.\left\{\mathrm{B}(\mathrm{OEt}) \mathrm{NHC}_{9} \mathrm{H}_{6} \mathrm{~N}\right\} \mathrm{Cl}(\mathrm{CO})\left(\mathrm{PPh}_{3}\right)_{2}\right]$ vs $\left[\mathrm{Os}\left(\mathrm{BNHC}_{9} \mathrm{H}_{6} \mathrm{~N}\right) \mathrm{Cl}_{2}(\mathrm{CO})\left(\mathrm{PPh}_{3}\right)_{2}\right]$ [31]. The nature of the bonding for compounds $\mathbf{5 b}$ and $\mathbf{5 c}$ are somewhat comparable to the known complexes, $[\mathrm{Mn}(\mu$ $\left.\mathrm{H})_{2}\left(\mathrm{BHNCSC}_{6} \mathrm{H}_{4}\right)\{\mathrm{NR}\}(\mathrm{CO})_{2}\left(\mathrm{PL}_{2} \mathrm{~L}^{\prime}\right)\right]$ vs $\left[\mathrm{Mn}(\mu-\mathrm{H})_{2}\left\{\mathrm{BHN}\left(\mathrm{NCSC}_{6} \mathrm{H}_{4}\right) \mathrm{R}\right\}(\mathrm{CO})_{2}\left(\mathrm{PL}_{2} \mathrm{~L}^{\prime}\right)\right](\mathrm{R}=\mathrm{NCS}-$ $\mathrm{C}_{6} \mathrm{H}_{4}, \mathrm{~L}=\mathrm{L}^{\prime}=\mathrm{Ph}$, or $\left.\mathrm{L}=\mathrm{Ph}, \mathrm{L}^{\prime}=\mathrm{Me}\right)[11]$ and $\left[\left(\eta^{4}-\mathrm{COD}\right) \mathrm{Rh}(\mu-\mathrm{H}) \mathrm{BHRh}\left(\mathrm{C}_{14} \mathrm{H}_{8} \mathrm{~N}_{3} \mathrm{~S}_{2}\right)_{3}\right][9 h]$. One of the interesting bonding features of $\mathbf{5 b}$ and $\mathbf{5 c}$ is the coordination modes of the central metal as well as the boron atom. In $\mathbf{5 b}$, the bonding of boron is similar to that of $\mathbf{3}$. The only difference between the geometry of $\mathbf{3}$ and $\mathbf{5 b}$ is the presence of a ${ }^{t} \mathrm{BuNC}$ ligand instead of CO. In contrast, the boron atom in 5c is bonded to the exocyclic nitrogen of the bbza unit, whereas $\mathrm{Mn}$ atom is coordinated to the endocyclic nitrogen.

\subsection{Reactivity of Mn-borate complex 6 with $\mathrm{PPh}_{3}$}

In order to check the lability of the $\mathrm{CO}$ ligands at $\mathbf{6}$, we treated it with $\mathrm{PPh}_{3}$ ligand under photolytic condition that yielded borate complex $\left[\mathrm{Mn}\left(\mathrm{CO}_{2}\right)\left\{\kappa^{3}-\mathrm{S}, \mathrm{S}^{\prime}, \mathrm{H}-\mathrm{H}_{2} \mathrm{~B}(\mathrm{mbz})_{2}\right\}\left(\mathrm{PPh}_{3}\right)\right], 7$ (Scheme 4). This compound was isolated as red solid by thin layer chromatographic (TLC) technique. The ${ }^{11} \mathrm{~B}\left\{{ }^{1} \mathrm{H}\right\}$ NMR spectrum of 7 shows sharp signal at $\delta=19.5 \mathrm{ppm}$. The ${ }^{1} \mathrm{H}$ NMR spectrum showed upfield resonances at $\delta=-9.67 \mathrm{ppm}$, which has been assigned to $\mathrm{Mn}-\mathrm{H}_{\mathrm{b}}-\mathrm{B}$ proton and the peak at $\delta=4.27$ ppm has been assigned for $\mathrm{B}-\mathrm{H}_{\mathrm{t}}$ proton. The ${ }^{31} \mathrm{P}\left\{{ }^{1} \mathrm{H}\right\}$ NMR exhibits singlet at $\delta=8.4$ ppm that confirms the presence of phosphine ligand. The IR spectrum show stretching frequencies, characteristics of $\mathrm{B}-\mathrm{H}_{\mathrm{t}}$ and $\mathrm{CO}$ ligands at 2468 and $1949 \mathrm{~cm}^{-1}$ respectively.

Suitable crystals were obtained by recrystallizing the prepared complex in hexane and $\mathrm{CH}_{2} \mathrm{Cl}_{2}$ mixture at $-5{ }^{\circ} \mathrm{C}$. The molecular structure of complex 7 was unambiguously determined by single 


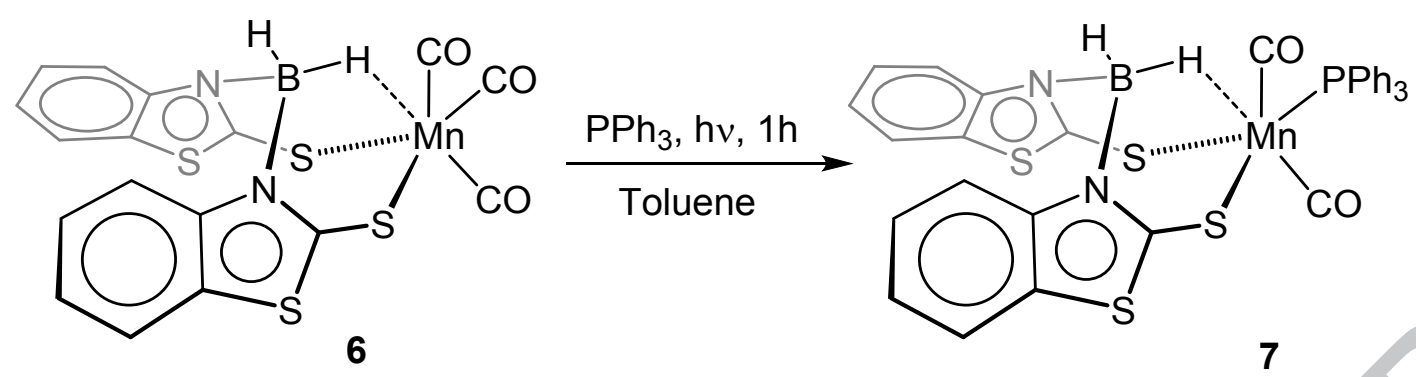

Scheme 4. Reactivity of complex 6 with $\mathrm{PPh}_{3}$

crystal X-ray crystallography (Figure 4). The crystals of 7 contain one molecule in their asymmetric unit cell. The solid state X-ray structure of 7 demonstrates that one of the CO ligands trans to $\mathrm{Mn} \cdots \mathrm{H}-$ $\mathrm{B}$ interaction in 7 has been replaced by $\mathrm{PPh}_{3}$ ligand. The borate ligand in 7 adopts a tridentate coordination mode, similar to parent compound $\mathbf{6}$. The only difference between the geometries of 6 and 7 is the presence of a $\mathrm{PPh}_{3}$ ligand instead of CO ligand. The bond distances of $\mathrm{Mn}-\mathrm{B}$ and $\mathrm{Mn} \cdots \mathrm{H}-\mathrm{B}$ in 7 (2.687(3) and 1.74(3) Å respectively) are comparable with that of parent compound 6 (2.699 and

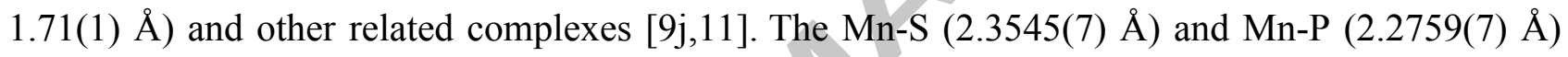
bond distances are within the range $[9 \mathrm{j}, 11]$.

Computational studies of Mn borate complex, 7: In order to know the nature of the metal to ligand coordination, we have performed the DFT calculations at BP86/Def2-SVP level [32], starting from the coordinates attained from the X-ray structure. A quick look into the molecular orbitals of 7

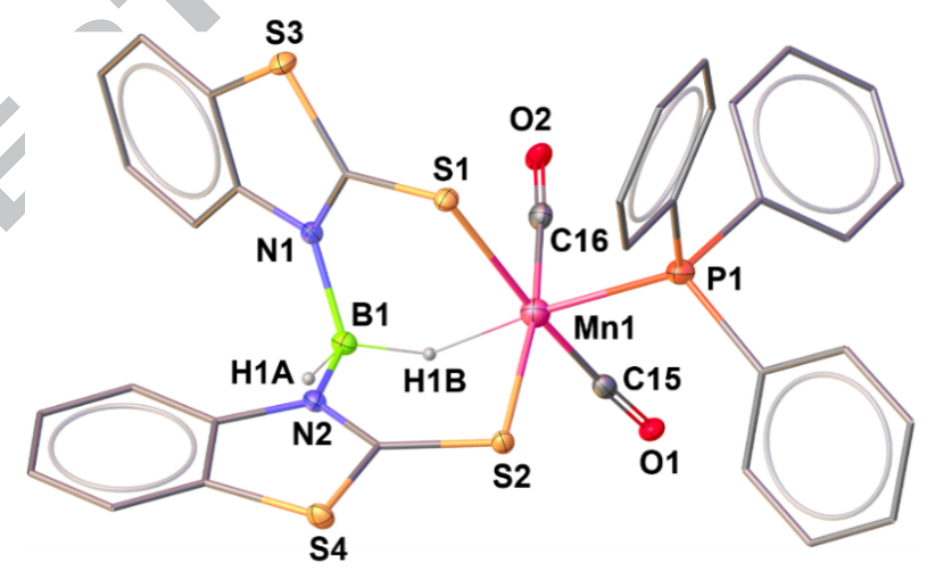

Figure 4. Molecular structure of compound 7 in the solid state. All hydrogen atoms have been removed for clarity. Selected bond lengths (Å): Mn1-B1 2.687(3), Mn1-H1B 1.74(3), Mn1-P1 2.2759(7), B1-H1B 1.19(3), B1-H1A 1.10(3), Mn1-S1 2.4295(7), B1-N1 1.561(3), B1-N2 1.554(3). 
suggests that the electron density at HOMO is located at manganese and carbonyl ligands whereas the LUMO is located on both manganese and one of the benzothiazole moieties of the borate ligand (Figure S25). The HOMO-LUMO gap for 7 is about $1.98 \mathrm{eV}$ less than that of parent compound 6 $(2.17 \mathrm{eV})$. From the NBO based second order perturbation analysis, the donor-acceptor interaction from the filled $\sigma(\mathrm{B}-\mathrm{H})$ orbitals to vacant orbitals of the manganese, the stabilizing energy of 82.33 $\mathrm{kcal} \mathrm{mole}^{-1}$ and the back donation of $30.12 \mathrm{kcal} \mathrm{mole}^{-1}$ were observed (Figure 5). The WBI's (Wiberg bond index) of compound 7 are comparable with those of 6.
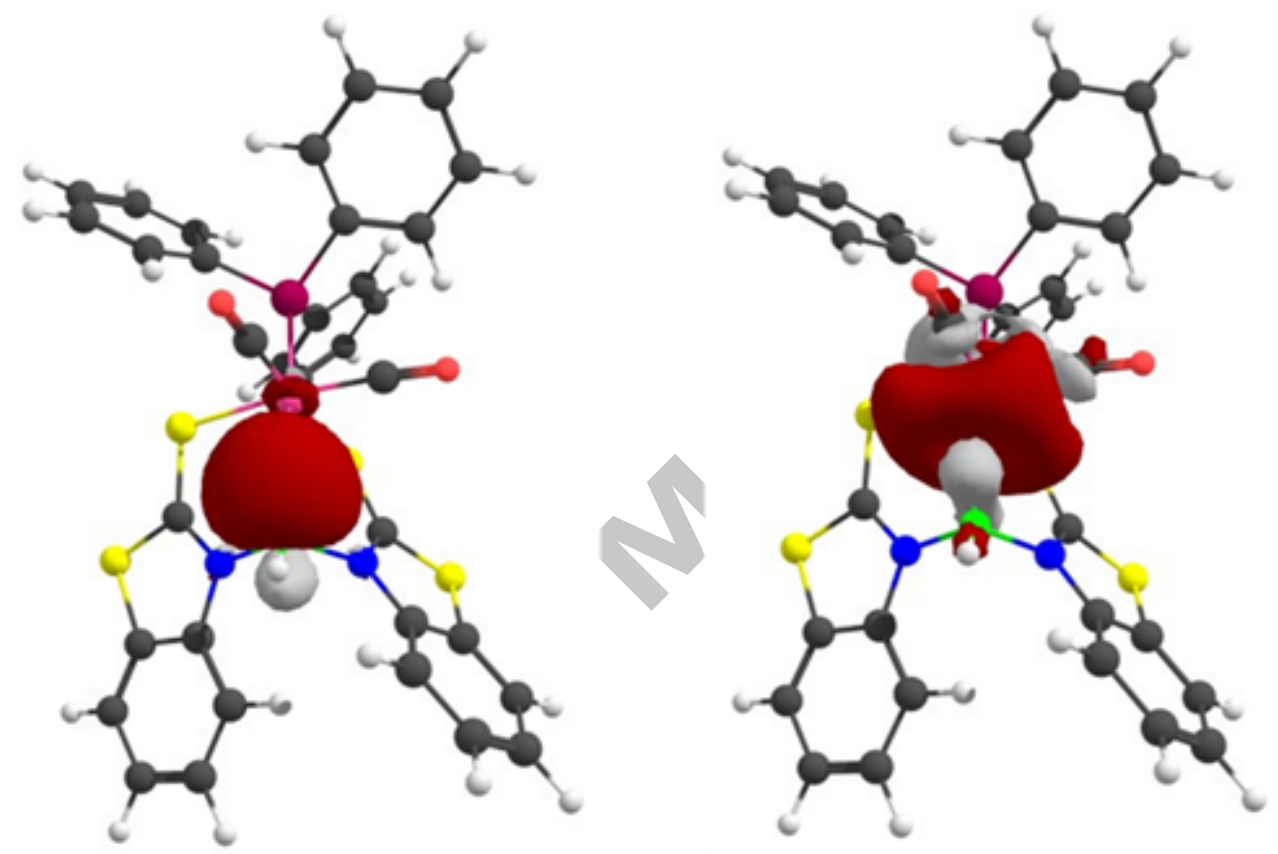

Figure 5. MOs responsible for $\sigma_{(\mathrm{B}-\mathrm{H})} \rightarrow \mathrm{Mn}$ interaction in 7 obtained from NBO analysis (contour value: $\left.\pm 0.03\left[\mathrm{e} / \mathrm{bohr}^{3}\right]^{1 / 2}\right)$.

\section{Conclusions}

In conclusion, we have described the synthesis and characterization of the rhenium complex containing bbza ligand. In addition, we have explored the reactivity of bis $(\sigma)$ borate and borate complexes of manganese with different tertiary phosphines and isocyanide ligand. The reaction of manganese bis $(\sigma)$ borate complex with excess phosphines led to the formation of manganese phosphine complexes. In contrast, the reaction with isocyanide ligand yielded ${ }^{t} \mathrm{BuNC}$-substituted bis $(\sigma)$ borate complexes of manganese. Reactivity of these borate complexes with other ligands are currently under investigation. 


\section{Acknowledgements}

The authors acknowledge the Council of Scientific \& Industrial Research (CSIR) (Project No. 01(2939)/18/emr-ii), New Delhi, India for financial support. C. N. thank Department of Science and Technology, DST-INSPIRE for research fellowship. K. S. and S. G. are thankful to Council of Scientific and Industrial Research (CSIR) and IIT Madras, respectively, for their research fellowships. IIT Madras is gratefully acknowledged for computational facilities.

\section{Appendix A. Supplementary data}

CCDC 1886985 (2), 1886987 (4a), 1886986 (4b) and 1835499 (7) contain the supplementary crystallographic data for this paper. These data can be obtained free of charge via http://www.ccdc.cam.ac.uk/conts/retrieving.html, or from the Cambridge Crystallographic Data Centre, 12 Union Road, Cambridge CB2 1EZ, UK; fax: (+44) 1223-336-033; or e-mail: deposit@ccdc.cam.ac.uk. Supplementary data associated with this article can be found, in the online version, at http://dx.doi.org

\section{References}

[33] (a) H.V.R. Dias, W. Jin, Inorg. Chem. 35 (1996) 3687; (b) A. Adach, J. Coord. Chem. 70 (2017) 757;

(c) M. Pellei, G.G. Lobbia, G. Papini, C. Santini, Mini Rev. Org. Chem. 7 (2010) 173; (d) C. Santini, M. Marinelli, M. Pellei, Eur. J. Inorg. Chem. (2016) 2312.

[34] L.F. Soares, D.C. Menezes, R.M. Silva, A.C. Doriguetto, J. Ellena, Y.P. Mascarenhas, E.E.Castellano, Polyhedron 23 (2004) 205.

[35] (a) S. Trofimenko, J. Am. Chem. Soc. 88 (1966) 1842; (b) S. Trofimenko, Scorpionates: The Coordination of Poly(pyrazolyl)-borate Ligands, Imperial College Press, London, 1999; (c) S. Trofimenko, Chem. Rev. 93 (1993) 943; (d) C. Pettinari, Scorpionates II: Chelating Borate Ligands, Imperial College Press, London, 2008; (e) M. Imran, B. Neumann, H. G. Stammler, U. Monkowius, M. Ertl, N. W. Mitzel, Dalton Trans. 43 (2014) 1267.

[36] (a) F. Tisato, C. Bolzati, A. Duatti, G. Bandoli, F. Refosco, Inorg. Chem. 32 (1993) 2042; (b) M. Videira, C. Moura, A. Datta, A. Paulo, I. C. Santos, I. Santos, Inog. Chem. 48 (2009) 4251; (c) C. S. Masui, J. M. Mayer, Inorg. Chim. Acta 251 (1996) 325; (d) M. Videira, L. Maria, A. Paulo, I. C. Santos, I. Santos, P. D. Vaz, M. J. Calhorda, Organometallics 27 (2008) 1334; (e) L, Maria, A. Paulo, I. C. Santos, I. Santos, P. Kurz, B. Spingler, R. Alberto, J. Am. Chem. Soc. 128 (2006) 14590; (f) J. 
Brugos, J. A. Cabeza, P. G. Álvarez, E. P. Carreño, J. F. V. Maelen, Dalton Trans. 46 (2017) 4009; (g) M.J. Abrams, A. Davison and A.G. Jones, Inorg. Chim. Acta, 82 (1984) 125.

[37] S. Schlecht, J. F. Hartwig, J. Am. Chem. Soc. 122 (2000) 9435.

[38] T. Kakizawa, Y. Kawano, and M. Shimoi, Organometallics. 20 (2001) 3213.

[39] (a) L. A. Graham, A. R. Fout, K. R. Kuehne, J. L. White, B. Mookherji, F. M. Marks, G. P. A. Yap, L. N. Zakharov, A. L. Rheingold, D. Rabinovich, Dalton Trans. (2005) 171; (b) A. H. Ilkhechi, S. L. Guo, M. Bolte, M. Wagner, Dalton Trans. (2003) 2303; (c) F. Hossain, M. A. Rigsby, C. T. Duncan, P. L. Milligan, Jr., R. L. Lord; M. H. Baik, F. A. Schultz, Inorg. Chem 46 (2007).2596.

[40] A. P. Forshaw, J. M. Smith, A. Ozarowski, J. Krzystek, D. Smirnov, S. A. Zvyagin, T. D. Harris, H. I. Karunadasa, J. M. Zadrozny, A. Schnegg, K. Holldack, T. A. Jackson, A. Alamiri, D. M. Barnes, J. Telser, Inorg. Chem 52 (2013).144; (b) S. V. Kolotilov, A. W. Addison, S. Trofimenko, W. Dougherty, V. V. Pavlishchuk, Inorg. Chem. Commun. 7 (2004) 485.

[41] (a) R. S. Anju, D. K. Roy, B. Mondal, K. Yuvaraj, C. Arivazhagan, K. Saha, B. Varghese, S. Ghosh, Angew. Chem., Int. Ed. 53 (2014) 2873; (b) D. K. Roy, A. De, S. Panda, B. Varghese, S. Ghosh, Chem. Eur. J. 21 (2015) 13732; (c) D. K. Roy, R. Borthakur, S. Bhattacharyya, V. Ramkumar, S. Ghosh, J. Organomet. Chem. 799-800 (2015) 132; (d) R. Ramalakshmi, K. Saha, D. K. Roy, B. Varghese, A. K. Phukan, S. Ghosh, Chem. Eur. J. 21 (2015) 17191; (e) D. K. Roy, B. Mondal, R. S. Anju and S. Ghosh, Chem. Eur. J. 21 (2015) 3640; (f) K. Saha, B. Joseph, R. Ramalakshmi, R. S. Anju, B. Varghese, S. Ghosh, Chem. Eur. J. 22 (2016) 7871; (g) B. Mondal, R. Borthakur, S. Ghosh, In Organometallic Chemistry and Catalysis of Transition Metal-Borane Compounds; World Scientific, Imperial College Press Ltd. (UK), 2018; (h) K. Saha, R. Ramalakshmi, R. Borthakur, S. Gomosta, K. Pathak, V. Dorcet, T. Roisnel, J.-F. Halet, S. Ghosh, Chem. Eur. J. 23 (2017) 18264; (i) K. Saha, B. Joseph, R. Borthakur, R. Ramalakshmi, T. Roisnel, S. Ghosh, Polyhedron 125 (2017) 246; (j) K. Saha, S. Gomosta, R. Ramalakshmi, B. Varghese, S. Ghosh, Proc. Natl. Acad. Sci., India, Sect. A Phys. Sci. 86 (2016) 521; (k) K. Saha, U. Kaur, S. Kar, B. Mondal, B Joseph, P.K.S. Antharjanam, S. Ghosh, Inorg. Chem. (2019).

[42] (a) H. Vahrenkamp, Acc. Chem. Res. 32 (1999) 589; (b) C. Kimblin, B. M. Bridgewater, T. Hascall, G. Parkin, J. Chem. Soc., Dalton Trans. (2000) 891; (c) C. Slugovc, I. Padilla-Martinez, S. Sirol, E. Carmona, Coord. Chem. Rev. 213 (2001) 129; (d) M.D. Spicer, J. Reglinski, Eur. J. Inorg. Chem. (2009) 1553; (e) M.M. Morlok, K.E. Janak, G. Zhu, D.A. Quarless, G. Parkin, J. Am. Chem. Soc. 127 (2005) 14039; (f) S. Bakbak, VK. Bhatia, C.D. Incarvito, A.L. Rheingold, D. Rabinovich, Polyhedron 20 (2001) 3343; (g) G. Alcaraz, S. Sabo-Etienne, Angew. Chem., Int. Ed. 2010, 49, 7170; (h) R.C. da Costa, B.W. 
Rawe, A. Iannetelli, G.J. Tizzard, S.J. Coles, A.J. Guwy, G.R. Owen, Inorg. Chem. 58 (2019) 359; (i) A. Kumar, N.A. Beattie, S.D. Pike, S.A. Macgregor, A.S. Weller, Angew. Chem., Int. Ed. 55 (2016) 6651; (j) G. Bouhadir, D. Bourissou, Coordination of Lewis Acids to Transition Metals: Z-Type Ligands, Springer, Heidelberg, 2016; (k) H. Braunschweig, R.D. Dewhurst, A. Schneider, Chem. Rev. 110 (2010) 3924.

[43] K. Saha, R. Ramalakshmi, S. Gomosta, K. Pathak, V. Dorcet, T. Roisnel, J.-F. Halet, S. Ghosh, Chem. Eur. J. 23 (2017) 9812.

[44] D.R. Dauer, M. Flügge, R.H. Irmer, D. Stalke, Dalton Trans. 45 (2016) 6136.

[45] G.E. Ryschkewitsch, K.C. Nainan, Inorg. Synth. 15 (1974) 113.

[46] Due to low yield of compound 2, the ${ }^{1} \mathrm{H}$ and ${ }^{13} \mathrm{C}\left\{{ }^{1} \mathrm{H}\right\}$ NMR spectra are not impressive and the spectroscopic assignments for compound $\mathbf{2}$ are not reported here.

[47] The total yields of $\mathbf{5 b}$ and $\mathbf{5 c}$ were $\sim 19 \%$; these two compounds were not analytically pure.

[48] A. Altomare, G. Cascarano, C. Giacovazzo, A. Guagliardi, M.C. Burla, G. Polidori, M. Camalli, J. Appl. Cryst. 27 (1994) 435.

[49] G.M. Sheldrick, Acta Cryst. A71 (2015) 3.

[50] G.M. Sheldrick, Acta Cryst. C71 (2015) 3.

[51] G. Bandoli, A. Dolmella, T.I.A. Gerbe, D. Luzipo, J.G.H. du Preez, Inorg. Chim. Acta 325 (2001) 215.

[52] T. Yasue, Y. Kawano, M. Shimoi, Angew. Chem., Int. Ed. 42 (2003) 1727.

[53] R.M. Meier, T.P. Hanusa, Structural Organomanganese Chemistry in PATAI'S Chemistry of Functional Groups (2011) John Wiley \& Sons, Ltd.

[54] G. Wilkinson, R.D. Gillard, J.A. McCleverty (Eds.), Comprehensive Coordination Chemistry, Pergamon Press, Oxford, 1987.

[55] J.A. McCleverty, T.J. Meyer (Eds.), Comprehensive Coordination Chemistry II, Elsevier, Oxford, 2004.

[56] C.A. McAuliffe, W. Levason, Phosphine, Arsine and Stibine Complexes of the Transition Elements, Elsevier, Amsterdam, 1979.

[57] G.O. Spessard, G.L. Miessler, Organometallic Chemistry, Prentice-Hall, Upper Saddle River, NJ, 1997. 
[58] R.H. Crabtree, The Organometallic Chemistry of the Transition Metals, 5th ed., John Wiley and Sons, 2009.

[59] N. Fey, A.G. Orpen, J.N. Harvey, Coord. Chem. Rev. 253 (2009) 704.

[60] (a) P.W.N.M. van Leeuwen, Homogeneous Catalysis Understanding the Art, Kluwer Academic Publishers, Dordrecht, 2004;(b) R.H. Crabtree, The Organometallic Chemistry of the Transition Metals, fourth ed., John Wiley \& Sons, 2005; (c) W. Tolman, Activation of Small Molecules: Organometallic and Bioinorganic Perspectives, Wiley-VCH, Weinheim, 2006.

[61] (a) J.G.J. Raj, Rev. Inorg. Chem. 35 (2015) 25; (b) C. D. Swor, D. R. Tyler, Coord. Chem. Rev. 255 (2011) 2860.

[62] A. Phanopoulos, N.J. Long, P.W. Miller, Triphosphine Ligands: Coordination Chemistry and Recent Catalytic Applications, Struct. Bonding (Berlin, Ger.) 171 (2016) 141.

[63] (a) C.E.F. Rickard, W.R. Roper, A. Williamson, L.J. Wright, Organometallics 21 (2002) 4862; (b) G.J. Irvine, C.E.F. Rickard, W.R. Roper, A. Williamson, L.J. Wright, Angew. Chem., Int. Ed. 39 (2000) 948.

[64] Geometry optimization was performed at the BP86/Def2-SVP level of theory. For full details see Supporting Information. 
Fine tuning of reactivity and structure of bis( $\sigma)$ borate and borate complexes of manganese by systematic ligand variation

Chandan Nandi ${ }^{\mathrm{a}}$, Koushik Saha ${ }^{\mathrm{a}}$, Suman Gomosta ${ }^{\mathrm{a}}$, Vincent Dorcet $^{\mathrm{b}}$, Sundargopal Ghosh ${ }^{\mathrm{a}, *}$

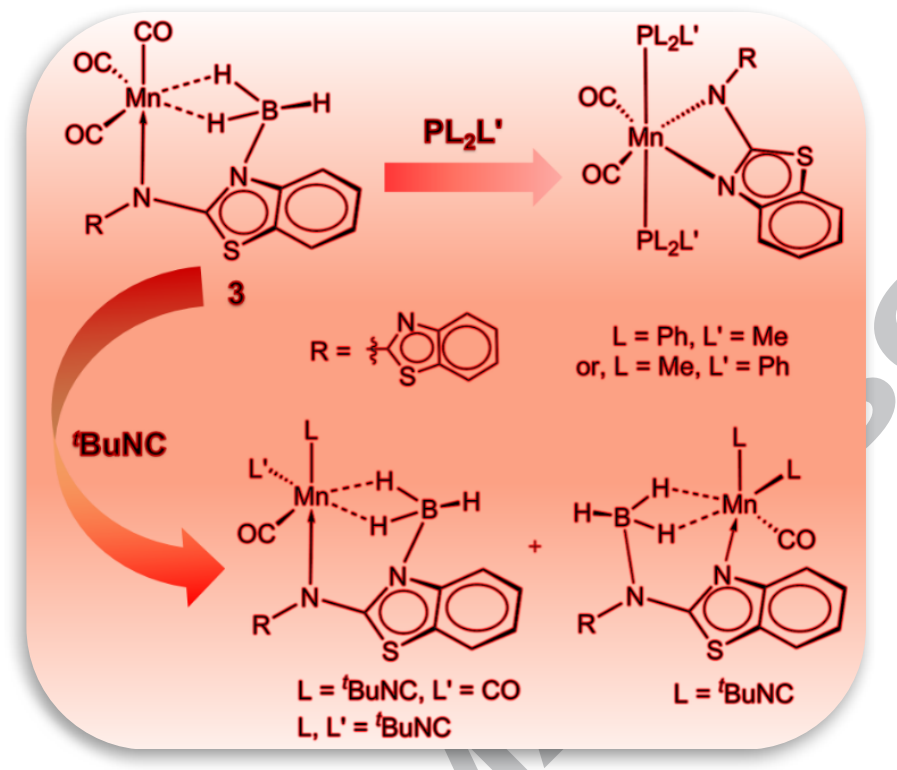

Photolysis of a manganese bis $(\sigma)$ borate complex, 3 with excess of phosphines yielded manganese phosphine complexes. In contrast, photolysis of $\mathbf{3}$ with ${ }^{t} \mathrm{BuNC}$ yielded mono/bis $\left({ }^{\mathrm{t}} \mathrm{BuNC}\right)$-substituted manganese borate complexes (see picture). 